\title{
HOOFSTUK 4 \\ Die verhouding tussen die narratiewe teks en die storie
}

\subsection{Inleiding}

Daar is reeds in hoofstuk 1.4 by die uiteensetting van die werkwyse gemeld dat Gérard Genette se model waarvolgens 'n narratiewe teks in drie vlakke onderskei kan word, gebruik sal word om die verhalende struktuur van die boek Jona te beskryf. Die drie vlakke is soos volg:

* die récit (narratiewe teks - Gräbe [1986:156] of vertelteks - Brink [1987:39]);

- die histoire (storie - Gräbe [1986:156]);

* die narration (vertelhandeling - Gräbe [1986:156] of vertelproses - Brink [1987: 40]).

Bostaande drie vlakke is op ' $n$ bepaalde manier aan mekaar verbind sodat die storie die inhoud (dieptestruktuur) van die narratiewe teks (oppervlakstruktuur) vorm, terwyl die vertelhandeling die wyse waarop die teks geproduseer is, weergee. Gräbe (1986:156) verduidelik hierdie interafhanklikheid tussen die drie vlakke van die verhaal met die volgende skets:

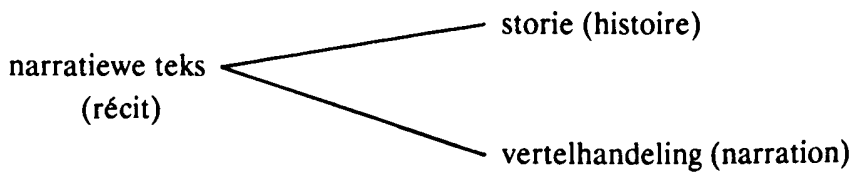

Alhoewel die storie en vertelhandeling slegs indirek uit die vertelteks afgelei kan word, is hulle noodsaaklik om sowel die verhaal se samestelling as sy betekenis te beskryf. Genette se uitgangspunt dat die verhaalanalise deurgaans 'n ondersoek van verskillende relasies is, word met die volgende aanhaling gedemonstreer: 'Analysis of narrative discourse will thus be for me, essentially, a study of the relationships between narrative and story, between narrative and narrating, and [to the extent that they are inscribed in the narrative discourse] between story and narrating' (my beklemtoning). In hierdie hoofstuk word dié spesifieke relasie tussen die narratiewe teks en die storie ondersoek soos dit gestalte vind in drie elemente naamlik tyd, karakterisering en ruimte.

\subsection{Tyd}

Dat tyd 'n belangrike formele element in narratiewe tekste is, blyk uit die rol wat dit as ordeningsbeginsel in die strukturering van die verhaal speel. Rimmon-Kenan 
(1983:58) konstateer hierdie feit soos volg: 'Moreover, while the treatment of time may undergo various changes, time itself is indispensable to both story and text. To eliminate it [if this were possible] would be to eliminate all narrative fiction.' Dié onontbeerlikheid van tyd as element vir beide die storie en die narratiewe teks, word op twee maniere gemanifesteer: Eerstens word gebeurtenisse in die storie volgens hulle logiese en chronologiese opeenvolging in die tyd georden; tweedens word gebeure, karakters en ruimte lineêr in terme van tyd in die narratiewe teks aangebied (Gräbe 1985:25).

Om die verhouding wat daar tussen tyd in die storie en die tyd wat in die vertelteks in Jona bestaan te bespreek, word dit aan die hand van die drie aspekte wat Genette onderskei het, gedoen, naamlik volgorde, duur en frekwensie.

\subsubsection{Volgorde}

By volgorde, so sê Gräbe (1988:25), 'gaan dit om die verhouding tussen die opeenvolging van die gebeurtenisse in die storie en hulle lineêre aanbieding in die verhalende teks'. As 'n parafrase van die storiegebeure uit die teks van Jona gemaak word, is dit duidelik dat aieselfde waarnemings wat Gräbe (1986:267) ten opsigte van die gelykenis van die barmhartige Samaritaan gemaak het, ook op Jona van toepassing kan wees. Na die volgende parafrasering sal verder op hierdie waarnemings ingegaan word.

\section{Parafrase:}

1 Nineve se boosheid het onder Jahwe se aandag gekom.

2 Gevolglik gee Jahwe sy profeet Jona opdrag om teen Nineve te gaan preek.

3 Jona wil hierdie opdrag ontduik deur per skip na Tarsis toe te probeer vlug.

4 Jahwe veroorsaak 'n hewige storm op die see, sodat die skip gevaar loop om te vergaan.

5 Terwyl die matrose alles in hulle vermoë doen om die skip te red, lê Jona in die ruim van die skip en slaap.

6 Ten einde raad werp hulle die lot en dit val op Jona.

7 Hy erken dat hy van Jahwe se opdrag wegvlug en stel voor dat hy in die see gegooi word.

8 Die matrose probeer eers om na die land toe terug te roei, maar dit is tevergeefs.

9 Nadat hulle tot Jahwe gebid het, gooi hulle Jona oorboord en die see word kalm.

10 Toe vrees die matrose Jahwe en gee aan hom offers en doen geloftes aan hom.

11 Intussen het Jahwe ' $n$ vis beskik om Jona in te sluk. 
12 Jona bly drie dae en nagte in die vis waar hy tot Jahwe bid.

13 Daarna beveel Jahwe die vis om Jona op land uit te spoeg.

14 Jahwe beveel Jona 'n tweede maal om teen Nineve te gaan preek.

15 Jona gehoorsaam en nadat hy 'n dagreis die stad ingegaan het, preek hy die boodskap wat Jahwe aan hom opgedra het.

16 Die mense van Nineve reageer positief op die preek.

17 Selfs die koning van Nineve kry berig van die preek en vaardig 'n dekreet uit wat almal tot berou en vas verplig.

18 God sien hulle optrede en trek sy oordeel terug.

19 Hieroor is Jona baie kwaad en bid tot Jahwe om sy lewe te neem.

20 Hy gaan toe die stad uit om aan die oostekant vir hom 'n skuiling te bou vanwaar hy kan sien wat met die stad gebeur.

21 Jahwe beskik toe 'n boompie om as skadu vir Jona te dien.

22 Hieroor is Jona baie bly.

23 Met dagbreek die volgende dag beskik Jahwe 'n wurm om die boompie te steek sodat dit verwelk.

24 Daarna, toe die son skyn, het God die Oostewind beskik om te waai sodat Jona flou geword het.

25 Toe hy bid om te sterf, vra God of hy rede het om kwaad te wees oor die boompie.

26 Wanneer hy bevestigend antwoord, vra God hoeveel te meer Hy nie rede het om genade aan die mense van Nineve te betoon nie.

Voordat oorgegaan word om die chronologiese opeenvolging van handelinge aan die hand van die storieparafrase te bespreek, is dit van belang om eers die basiese struktuur van die verhaal op die storievlak aan die hand van Bremond (Gräbe 1985b:63-66) se model van die 'logika van die narratiewe moontlikheid' na te gaan. Hierdie model word gegrond op die veronderstelling dat funksie die basiese eenheid van 'n storie is, maar dat dit verbind word met 'n reeks waar verskillende alternatiewe vir die ontwikkeling van die storie moontlik is. So 'n reeks gebeurtenisse vorm 'n proses waarbinne drie stadia onderskei kan word, naamlik:

* die moontlikheid (of virtualiteit);

* die gebeurtenis self (of aktualisering);

* die resultaat (of afsluiting) van die proses.

Volgens Bremond ontwikkel alle reekse in verbeterings- of verslegtingsprosesse. Toegepas op die Jonaverhaal kan die volgende prosesse van verbetering of versleg- 
ting onderskei word. In die eerste deel van die boek wat uit hoofstukke 1 en 2 bestaan, sien die prosesse soos volg daar uit:

* met die bevel van Jahwe in Jona 1:2 word die moontlikheid of virtualiteit gestel, met ander woorde 'n doel word gedefinieer;

* met Jona se reaksie in Jona 1:3 vind daar 'n nie-aktualisering plaas van die proses om die doel te bereik;

* die resultaat van die nie-aktualisering is mislukking en daarom word 'n verslegtingsproses met die storm ingelei en verder gevoer wanneer Jona uiteindelik oorboord gegooi word. Hierdie verslegtingsproses, wat met die storm begin, word voortdurend geïntensiveer totdat dit 'n klimaks bereik wanneer Jona oorboord gegooi word. Daarna tree 'n verbeteringsproses in wanneer Jona deur die vis ingesluk word en vervolgens op land uitgespoeg word.

'n Byna identiese verloop in die tweede deel van die boek, wat uit hoofstukke 3 en 4 bestaan, kan soos volg beskryf word:

* met die herhaling van Jahwe se bevel in Jona 3:2 word daar weer 'n moontlikheid gestel;

* met die positiewe reaksie van Jona betreffende hierdie bevel word die aktualisering van die doel in werking gestel;

* Nineve se reaksie as die resultaat van die aktualisering word op 'n negatiewe wyse deur Jona ervaar en kan daarom as 'n verslegtingsproses getipeer word. Net soos in die eerste helfte van die boek word hierdie verslegtingsproses ook geïntensiveer deur die episode van die boompie wat aanvanklik positief begin, maar dan dramaties versleg. Anders as in die eerste helfte van die boek, word die verbeteringsproses hier nie eksplisiet gestel nie, maar slegs gesuggereer deur die oop einde van die boek. Die veronderstelling is dat Jona die korrekte antwoord sou gee en dat die resultaat dan vir hom positief sou wees. Slegs deur die aanname van hierdie veronderstelling word die virtualiteit wat in Jona 3:2 gestel is ten volle gerealiseer.

Uit bostaande storieparafrase en die verbeterings- en verslegtingsprosesse wat daaruit geabstraheer kan word, blyk dit dat, met die uitsondering van moontlik twee gebeurtenisse, die res mekaar ook chronologies in die vertelteks opvolg. Deist (1981: 18,40 ) wys met die term 'tydsvurk' na drie plekke in die teks waar gebeurtenisse gelyktydig gebeur, maar dan in die teks ná mekaar vertel word. Die drie passasies waarna hy verwys, is Jona 1:4-5 (vgl verse $4 \& 5$ hierbo), Jona 1:16-2:1 (vgl verse 911), asook Jona 3:4, daarmee korresponderende Jona 4:5 (vgl verse $15 \& 20$ ). Van der Woude (1978a:22) identifiseer hierdie selfde verskynsel, wat hy 'nachholende 
Erzählung' noem, ook in Jona 1:10 en 3:6v. Met hierdie 'stylfiguur' verstaan Van der Woude dat 'n saak eers in die algemeen gestel word en dus 'plusquamperfektisch' vertaal moet word en dan daarna in besonderhede weergegee word.

Die vraag is of die voorkoms van hierdie stylfiguur (Van der Woude) of 'tydsvurk' (Deist) as 'n tydsafwyking of anachronie in Genette se terme beskou moet word. Die antwoord op hierdie vraag lê in die noodwendigheid van die lineêre aanbieding in ' $n$ vertelteks en aan die hand daarvan sal elkeen van die individuele gevalle bespreek word.

By 1:5 word eers die matrose en daarna Jona se reaksie op die storm uitgebeeld. Dit is interessant dat beide se reaksie deur middel van drie handelinge weergegee word. Hierdie reaksies word op so 'n wyse uitgebeeld dat dit 'n perfekte kontras met mekaar vorm. Omdat hierdie kontras later onder 'karakterisering' volledig bespreek sal word, word daar nou nie in detail daarop ingegaan nie. Die gelyktydige weergawe van die reaksies op die storievlak kan nie anders as lineêr in die narratiewe teks gestalte kry nie. Daarom is daar geen sprake van afwyking in chronologiese orde van tyd soos dit in die teks neerslag vind nie.

Op 'n soortgelyke wyse word gebeurtenisse wat gelyktydig plaasvind nadat Jona in Jona 1:15 in die see gegooi is, ook lineêr aangebied. Alhoewel die matrose se handelinge (Jona 1:16) en die vis wat vir Jona insluk (Jona 2:1) gelyktydig plaasvind, word die gebeure rondom die matrose se optrede eerste vertel en daarna die gebeure rondom Jona. Ook hier is geen sprake van afwyking in die chronologiese patroon nie, maar kom die gebeurtenisse lineêr in die teks voor. Die feit dat 'n belangrike konvensie soos die artistieke herrangskikking van logiese en chronologiese gebeurtenisse op die teksvlak in beide bogenoemde gevalle nie geëksploiteer word nie, vra om 'n verklaring. Die saamval van die gebeure op die storievlak met die verhaalvlak het tot gevolg dat die dieptestruktuur van die storie direk na die oppervlakstruktuur van die narratiewe teks verplaas word. Gevolglik word die inhoud of betekenis van die verhaal daardeur makliker verstaanbaar - oftewel, die didaktiese les word direk gekommunikeer (Gräbe 1986:269).

In beide bogenoemde gevalle, asook by Jona 1:10 en 3:5 waar gelyktydige handelinge plaasvind, is dit interessant om daarop te let dat die matrose en die Nineviete se reaksie telkens eerste weergegee word voordat Jona se optrede belig word. Die vraag is waarom hierdie volgorde konsekwent gevolg word, terwyl Lohfink (1961:195) dit beklemtoon dat '[s]chliesslich ist es das Jonabuch, und um Jona geht es'. Is dit nie die manier waarop die verteller telkens die religieuse reaksie van die heidene wil beklemtoon teenoor die byna traak-my-nieagtige houding van Jona nie? Sodoende kry ons 'n onverwagte reaksie van die heidene, terwyl die man van wie ons dit wel verwag, nie aan die verwagting voldoen nie. Dit is om hierdie rede dat 
Lohfink (1961:196) die motivering vir hierdie tegniek soek in '[w]ieder war die Kategorie der religiösen Reaktion führend'.

Wat Van der Woude se term 'nachholende Erzählung' betref, kan dit slegs op twee passasies betrekking hê, naamlik Jona 1:16 en 3:5-9. Alleen in hierdie gevalle kan daar werklik sprake wees van ' $n$ frase of sin wat 'n voorafgaande frase of sin nader spesifiseer. So word by Jona 1:16 die 'bring van offers' deur 'hulle het naamlik geloftes afgelê' verduidelik. In Jona 3:5 word die algemene reaksie van die mense van Nineve opgevolg deur die dekreet van die koning in Jona 3:6-9 waarin die vereiste optrede in detail uitgespel word. Inderdaad word ook hier die chronologiese en logiese weergawe van gebeurtenisse lineêr in die vertelteks aangebied.

'n Veel moeiliker geval is die voorstel dat Jona 4:5 direk na 3:4 moet volg omdat dit 'n logiese vervolg op die gebeure in Jona 3:4 sou wees. Daarmee word veronderstel dat as Jona 4:5 sy posisie behou, daar'n tydsafwyking in die teks ontstaan. Volgens Lohfink (1961:185) was Winckler die eerste van 'n lang ry geleerdes wat hierdie voorstel ondersteun het. Saam met Lohfink verwerp ek hierdie voorstel omdat die gebeurtenisse in die teks wel logies en chronologies op mekaar volg. Eers preek Jona (in Jona 3:4), dan kom die Nineviete tot inkeer (Jona 3:5-9), daarna weerhou Jahwe sy oordeel (Jona 3:10) en daarom is Jona so kwaad dat hy bid om te sterf. Dus is dit myns insiens duidelik dat die logiese en chronologiese patroon op die storievlak nie op die teksvlak versteur word nie. By Jona 4:5 het ons met 'n nuwe ruimte-aanduiding te doen waar die volgende gebeurtenis hom afspeel; daarop sal later ingegaan word as die aspek van ruimte bespreek word.

Daar is wel twee plekke waar tydsafwykings in die teks voorkom: Die eerste is by Jona 1:10 en die tweede by Jona 4:2. In albei gevalle het ons met terugflitse of, wat Genette noem, analepsisse, te doen. Lohfink (1961:194) wys daarop dat die gebeurtenisse by Jona 1:10 op die storievlak in die volgende volgorde geskied:

* Jona vertel hulle dat hy van Jahwe se opdrag af wegvlug.

* So kom die matrose te wete dat hy vlug.

* Daarna volg hulle uitroep van verbasing oor sy optrede.

In die narratiewe teks word die orde egter omgekeer. In Jona 1:9 word in die teks nie ekplisiet gestel dat Jona hulle meedeel dat hy vlug nie. In Jona 1:10 begin die orde by hulle uitroep, 'Wat is dit wat jy doen?', gevolg deur die mededeling dat hulle weet dat hy vlug omdat hy hulle dit vertel het. Die funksie van hierdie terugflits (omkering) is volgens Lohfink (1961:194) daarin geleë dat die vreesreaksie van die matrose direk na die belydenis van Jona moet volg. Dit gaan dus om die kontrastering van die vreesreaksie van die matrose met die statiese houding van Jona. 
'n Tweede terugflits kry ons in Jona se gebed in Jona 4:2. Hier hoor ons vir die eerste keer van Jona se bedenkinge wat hy gehad het toe hy sy opdrag die eerste maal ontvang het. Omdat hy die genadige aard van Jahwe geken het, het hy probeer om na Tarsis toe te vlug eerder as om sy opdrag na te kom. Daar kan dus gevra word waarom hierdie motivering vir sy optrede nou eers gestel word. Dit wil voorkom asof die spanningslyn daardeur verhoog word, die konflik geïntensiveer en sekere karaktereienskappe van Jona geopenbaar word. Wanneer karakterisering later bespreek word, sal hierdie aspek in diepte ondersoek word.

In beide gevalle het ons met die eerste kategorie van Genette se 'internal homodiegetic analepses' te doen (Genette 1980:51). Hieronder verstaan hy 'completing analepses, or "returns" [which] comprise[s] the retrospective sections that fill in, after the event, an earlier gap in the narrative...' (Genette 1980:51). Hierdeur word informasie aangaande die karakter van Jona wat betrekking het op sy optrede en innerlike gesteldheid in die verlede geopenbaar op 'n tydstip in die teks waar motivering vir sy handeling noodsaaklik is. Teen die agtergrond van hierdie inligting kan die ontsteltenis van die matrose in Jona 1:10 en Jona se eie ontsteltenis en sy doodswens in Jona 4:1-3 werklik begryp word.

Met die uitsondering van bogenoemde twee gevalle van analepsis val die chronologiese aanbieding van die gebeure in die storie en die teks saam. In haar bespreking van die gelykenis van die barmhartige Samaritaan, waar 'n soortgelyke saamval van die gebeure in die storie en die vertelteks voorkom, maak Gräbe (1986:267) die opmerking dat die struktuur van die teks ooreenstem met dié van 'n sprokie. Hierdie ongekompliseerde weergawe van die gebeure in die teks het tot gevolg dat 'n meer artistieke weergawe van die opeenvolging van gebeurtenisse nie benut word nie. Gevolglik kommunikeer die inhoud van die storie direk op die oppervlak van die teks en val die klem eerder op die betekenis van die verhaal. In die Jonaverhaal word so 'n direkte manifestering van 'betekenis' gevind. Dit geskied deur die onderskeie houdings van die akteurs teenoor Jahwe in die storie op die voorgrond te stel. Daarby word die volgorde waarin die akteurs se reaksies weergegee word éérs die heidene en dan Jona se reaksie - gebruik om hierdie twee houdings te kontrasteer. Die fyn balans in die konstruksie van die handelinge van die akteurs dra verder daartoe by dat die twee verskillende houdings pertinent by die leser registreer. Aan die hand van hierdie houdings word die betekenis of boodskap van die verhaal op 'n didaktiese wyse oorgedra.

\subsubsection{Duur}

Verklarings oor die duur van gebeurtenisse in die storie en die teks verskaf 'n antwoord op die vraag hoe lank die gebeure in terme van ure, dae, weke en jare ge- 
neem het om voltrek te word. Dit is egter problematies om dieselfde norm vir die duur van die gebeure in die storie en in die vertelteks vas te lê, want tyd in die vertelteks kan slegs in terme van vertelruimte gemeet word. Daarom moet ons met Genette saamstem 'to use constancy of pace, rather than adequation of story and text as the "norm" against which to examine degrees of duration. Constancy of pace in narrative is the unchanged ratio between story-duration and textual length...' (Rimmon-Kenan 1983:52). In die Jonaverhaal kom dit dus daarop neer dat die duur van 'n gebeurtenis in die storie in die teks manifesteer in die vorm van verse, perikope en bladsye. As konstante tempo die norm of die maatstaf is waarmee tydsduur gemeet word, kan dit gewysig word deur versnelling of vertraging.

Die globale ritme van 'n verhaal word deur afwisseling tussen die versnelling en vertraging in die narratiewe teks bewerkstellig (Bal 1978:74). Hierdie ritme kan volgens Genette (1980:95) op vier maniere aangepas word. Gräbe (1985b:29) voeg 'n vyfde wyse by wat sy na aanleiding van Chatman (1978) vertraging noem, maar Brink (1987:102) verkies die term uitbreiding. Dit word gedoen om asimmetrie uit te skakel deur ' $n$ teenpool vir samevatting daar te stel. Hierdie tempowisselings word deur die volgende aangepaste skema van Genette soos volg onderskei:

$\begin{array}{ll}\text { ellips: } \mathrm{TS}=\mathrm{n} \text { TV }=\mathrm{O} \text { dus: } & \text { TS }>\text { OO TV } \\ \text { samevatting } & \text { TS }>\text { TV } \\ \text { scène } & \text { TS }=\text { TV } \\ \text { uitbreiding } & \text { TS }<\text { TV } \\ \text { pouse: } \mathrm{TS}=\mathrm{O} \text { TV }=\mathrm{n} \text { dus: } & \text { TS }<\text { OO TV (Bal 1978:76) }\end{array}$

TS - storietyd

TV - verhaaltyd

$>$ - groter as

$<-$ kleiner as

$\mathrm{OO}$ - oneindig

$=-$ is gelyk

Hierdie skema kan soos volg verduidelik word:

* Ellips, waar die storiegebeure in die vertelteks weggelaat word.

* Samevatting, waar die storiegebeure opsommenderwys in die vertelteks weergegee word.

* Scène, waar die tempo van die storiegebeure gelyk is aan die verteltempo.

* Uitbreiding, waar die storiegebeure meer uitgebreid in die narratiewe teks voorkom. 
- Pouse, waar 'n element wat geen tyd in die storie in beslag neem nie, uitvoerig in die narratiewe teks vertel word (Gräbe 1985b:29).

Omdat Jona 'n kortverhaal is, word die tekstyd anders as by 'n roman of novelle nie aan die aantal bladsye gemeet nie, maar eerder aan die aantal verse wat aan 'n bepaalde episode afgestaan word. Wanneer hierdie globale ritme van die boek Jona ontleed word, is dit duidelik dat tempowisseling op die volgende wyse aangewend word:

* Hoewel die direkte rede wat 'n tipiese toneelmatige aanduiding is wel in Jona 1:1 voorkom, word in Jona 1:1-3 van samevatting gebruik gemaak, aangesien die storiegebeure van die roeping en opdrag van Jona in sy vaderland en sy reaksie daarop, slegs in drie verse in die vertelteks meegedeel word. Daar word nie vertel hóé, waar en wannéér hy die opdrag ontvang het nie; ook nie hoe hy na Joppe gereis het nie. Hierdie proses op die storievlak van roeping en opdrag en die wegvlug van hierdie opdrag moes ten minste 'n paar dae in beslag geneem het, maar die uitbeelding daarvan word in 'n beperkte ruimte in die vertelteks weergegee.

* Die gebeure tydens die storm op die skip word toneelmatig aangebied, met ander woorde, die tempo tussen die gebeure in die storie en die tempo waarmee dit in die teks weergegee word, is gelyk. Volgens Rimmon-Kenan (1983:54) is 'dialogue the purest form of scene'. Uit die dertien verse waarmee hierdie gebeure in die teks weergegee word, word agt verse geheel of gedeeltelik aan dialoog gewy. Dat hierdie gebeure met dertien verse in die teks uitgebeeld word, wys op die belangrikheid daarvan vir die verhaal. Nie alleen kom die onderskeie houdings van die akteurs uit die dialoog na vore nie, maar hierdie gebeure geld ook as antisipasie van dit wat nog moet volg, naamlik, die reaksie van die mense van Nineve.

* Die gebed van Jona in die maag van die vis (Jona 2:1-11) is 'n klassieke voorbeeld van 'n tempostilstand of pouse. Trouens, Licht (1978:123) noem dit 'n 'poetical intermezzo, enforcing a pause in the flow of the prose'. Alhoewel die enigste gebeure in die storie deur twee verse aan die begin en een vers aan die einde van die gebed gestel word, word agt verse in die teks aan die gebed self gewy. Wat die ritme van die verhaal betref, is dit duidelik dat dit hier tot stilstand gekom het. Volgens die tydsaanduiding in die storie, duur hierdie gebeure, of liewer die gebrek aan gebeure, drie dae en nagte. Uit die aard van die saak val die klem nie op die gebeure nie, maar verskuif dit na die innerlike gesteldheid van die akteur. Soos uit hoofstuk 3 blyk, gaan dit dus hier eerder om sy refleksie op die gebeure as om die gebeure self. Die funksie van hierdie pou- 
se sal later by karakterisering en fokalisering nader toegelig word. In hierdie stadium is dit slegs belangrik om die totale vertraging in die verteltempo uit te wys.

- Na die vertraging van die tempo met die episode in die vis, versnel die tempo aansienlik as 'n nuwe opdrag aan Jona geskets word met sy reaksie daarop (Jona 3:1-3). Net soos met die eerste roeping in Jona 1:1-3 word hierdie gebeure samevattend in drie verse vertel. Van die lang reis na Nineve in die storie, word niks in die teks gemeld nie, behalwe dat hy volgens Jahwe se woord na Nineve gegaan het. Uit die beskrywing van Nineve se grootte in Jona 3:3b word op 'n implisiete wyse aangetoon dat Jona in Nineve aangekom het. Verder dien hierdie beskrywing ook as oorgang na die volgende episode en is daarom minder belangrik as dié gedeeltes wat toneelmatig vertel word.

* Die gebeurereeks in Nineve wat met Jona se preek in Jona 3:4 begin en met Jahwe se vraag aan hom in Jona 4:4 eindig, word op 'n soortgelyke wyse as die ooreenstemmende episode in die eerste helfte van die boek toneelmatig weergegee. In teenstelling met die episode op die skip, is hier geen dialoog nie. Daar word wel vier maal in hierdie gedeelte gepraat:

** Jona se preek in Jona 3:4;

** die koning se opdrag in Jona 3:7-9;

** Jona se gebed in Jona 4:2;

** Jahwe se vraag aan Jona in Jona 4:4.

Hierdie vier gevalle word slegs gerapporteer sonder dat daar enige dialoog op volg. Lohfink (1961:197) wys daarop dat die gebeurereeks vanaf Jona 3:4-4:4 'gestaltet ein richtiges Hin und Her religiösen Geschehens, wo eine Reaktion die andere hervorruft'. Die prediking bewerk boetedoening en dié boetedoening word in groot detail bespreek sodat die toneel as ' $t$ ware voor die leser se oë afspeel. As gevolg van die volledigheid waarmee die boetedoening geskets word, kom die leser en Jahwe onder die indruk van ware berou en dit veroorsaak dat God sy straf herroep. In sowel die optrede van die Nineviete en die wyse waarop dit toneelmatig in die teks weergegee word, word ' $n$ baie sterk parallel met die episode van die matrose getrek. Beide die matrose en die Nineviete reageer op soortgelyke wyse op die woorde en dade van Jahwe. Jona daarenteen reageer met woede en ' $n$ wens om te sterf. Deur die gebed van Jona in Jona 4:2-3 wat as 'n pouse gesien kan word, word 'n selektiewe vertraging van die tempo binne 'n kompakte vertelling bewerkstellig.

* By Jona 4:5 begin 'n nuwe episode wat buite die stad afspeel. Die tyd wat die storie-gebeure in beslag neem kan hoogstens 'n paar dae wees en dit word as 'n 
scéne in die teks aangebied. Dat die tempo tussen storietyd en verteltyd hier gelyk is, word daardeur bevestig dat die helfte van die sewe verse wat die gebeure uitdruk, dialoog bevat. As hierdie dialoog nog in die strategiese laaste gedeelte van die episode tussen Jahwe en Jona voorkom, beklemtoon dit die belangrikheid van die episode. Die belangrikheid lê daarin dat die ontknoping van die verhaal in hierdie episode plaasvind en dat deur die toneelmatige aanbieding die inhoud van die storiegebeure in die narratiewe diskoers deursigtig word.

\subsubsection{Frekwensie}

Hierdie verskynsel wat heel eerste deur Genette as 'n aspek van tyd binne 'n literêrteoretiese model verwerk is, beantwoord die vraag hoe dikwels 'n gebeure in die storie plaasvind en hoe dikwels dit in die teks vertel word. Rimmon-Kenan (1983:56) som frekwensie soos volg op: 'Frequency...is the relation between the number of times an event appears in the story and the number of times it is narrated [or mentioned] in the text. Frequency, then, involves repetition, and repetition is a mental construct attained by an elimination of the specific qualities of each occurrence and a preservation of only those qualities which it shares with similar occurrences.' Genette (1980:114) onderskei vier moontlike relasies van repetisie tussen die storie en die teks, naamlik:

* om een keer te vertel wat een keer gebeur het (1N/1S);

* om $n$ kere te vertel wat $n$ kere gebeur het $(\mathrm{nN} / \mathrm{nS})$;

* om $n$ kere te vertel wat een keer gebeur het $(\mathrm{nN} / 1 \mathrm{~S})$;

* om een keer te vertel wat $n$ kere gebeur het $(1 \mathrm{~N} / \mathrm{nS})$.

Hoewel Genette beide die eerste twee tipes 'singulative narrative' noem, is dit die tweede tipe singulative narrative wat vir die bespreking van Jona van uiterste belang is.

Omdat repetisie so dikwels en op so 'n geskakeerde wyse in Ou-Testamentiese verhale voorkom, het verskeie navorsers soos Licht (1978:51-95), Alter (1981:88$113)$ en Sternberg (1985:365-440) reeds aan hierdie verskynsel aandag gegee. Alhoewel hulle dit meestal deskriptief en nie binne 'n algemeen literêr-teoretiese model bespreek het nie, is hulle insigte van belang omdat dit spesifiek toepaslik is op die Hebreeuse verhaalkuns van die Ou Testament. Verder is dit ook noodsaaklik om hulle waarnemings oor repetisie onder die aspek van frekwensie in Genette se model te akkommodeer om dit dan binne hierdie verband ook op Jona toepaslik te maak.

Alter (1981:95) se bydrae is veral daarin geleë dat hy die eenhede wat herhaal, saamsnoer tot wat hy noem, 'What we find, then, in biblical narrative is an elabora- 
tely integrated system of repetitions...' (my beklemtoning). Hierdie sisteem word voorgestel as 'a scale of repetitive structuring and focusing devices...running from the smallest and most unitary elements to the largest and most composite ones' en bestaan uit die volgende elemente:

1) Leitwort: Hier is die eenheid wat herhaal word die Hebreeuse woordstam. 'n Netwerk van relasies kan deur middel van die herhaling van hierdie basiese element tot stand gebring word.

2) Motif: Dit is 'n konkrete beeld, 'n waarneming, 'n gebeure wat herhaaldelik in 'n verhaal voorkom en soms met 'n Leitwort geassosieer word.

3) Theme: 'n Idee wat deel van die waardesisteem van die verhaal vorm en wat moreel, psigologies, polities of teologies kan wees, word deur herhaling duidelik weergegee.

4) Sequence of actions: Hierdie vorm van herhaling kom meestal in volksverhale voor waar 'n bepaalde gebeurereeks drie maal, of drie maal plus een, herhaal word.

5) Type-scene: Dit is 'n betekenisvolle episode in die lewe van 'n karakter waarin motiewe in 'n vasgestelde volgorde voorkom (Alter 1981:95-96).

Terme soos 'small scale repetitions' en 'tricola' wat deur Licht (1978:86, 90) gebruik word, kan onder punte 2, 3 en 4 in bogenoemde skema verdiskonteer word. Dit wat egter deur Magonet (1976:31) as 'the growing phrase' in Jona geïdentifiseer is, word deur Alter (1981:97) soos volg uitgesonder: 'But there is a different kind of biblical repetition, which is phrasal rather than verbal or a matter of motif, theme, and action. Here entire statements are repeated, either by different characters, by the narrator, or by the narrator and one or more of the characters in concert, with small but important changes introduced in what usually looks at first glance like verbatim repetition' (my beklemtoning).

Terwyl wat hierbo oor repetisie in Bybelse verhale gesê is, slegs oor die wat en die omvang van herhaling gehandel het, kan die afleiding ten onregte gemaak word dat herhaling slegs ' $n$ narratiewe konvensie in Bybelse verhale is. Sternberg (1985: 369) en Alter (1981:103) stem egter saam dat herhaling nie slegs 'n gesofistikeerde konvensie in Ou-Testametiese verhale is nie, maar inderdaad 'n funksionele prinsiep is. Volgens Sternberg (1985:411) funksioneer repetisie op tweërlei wyse, naamlik op die mimetiese en esteties-retoriese vlakke van die verhaal.

Sternberg (1985:430-435) gaan verder as Alter en hy poog ook om aan te toon hoe die herhalingspatroon bewerkstellig word. Hiervoor identifiseer hy vyf veranderlikes wat op drie asverhoudings as teenpole van mekaar gestel word. Dié drie asverhoudings is: 
* Die as van die objek waar die status van die objek op 'n verbale of nonverbale wyse vergestalt word;

- Die as van ekwivalensie waar die opponerende pole 'n verbatim weergawe of 'n variante herhaling is;

- Die as van motivering waar die variante weergawe as doelbewus of onbewustelik getipeer word.

Terwyl Bybelse verhale in die algemeen en die boek Jona in die besonder min gebruikmaak van die narratiewe tegniek waar die chronologiese en logiese volgorde van die storiegebeure in die teks herrangskik word, is dit heeltemal 'n ander saak wat frekwensie betref. Dit lyk of die artistiek-estetiese vermoë van Bybelse outeurs en van Jona in die besonder veral deur repetisie uitgelig word. Repetisie is dus nie 'n blote konvensie nie, maar word funksioneel ingespan om op beperkte of omvangryke wyse elemente te herhaal om bepaalde effekte te bereik. Die funksie van repetisie en ook ander naratiewe konvensies is dus kommunikatief van aard. Hierdie verskynsel van repetisie word hier onder aan die hand van bostaande beginsels in die boek Jona toegepas.

Die hele makrostruktuur van die boek is op die beginsel van repetisie saamgestel. So bestaan die boek uit twee duidelik onderskeibare helftes, $A$ en $B$, wat uit hoofstukke $1+2$ en $3+4$ onderskeidelik saamgestel is. Hierdie twee dele is op 'n soortgelyke wyse gestruktureer deurdat:

- albei op identiese wyse met die roeping en opdrag van Jona begin - vergelyk Jona 1:1-3 met 3:1-3;

* albei 'n 'getuienis' van Jona teenoor die heidene bevat, naamlik sy belydenis in Jona 1:9 en sy preek in 3:4;

* albei gee 'n positiewe reaksie van die heidene op Jona se 'getuienis'. Die matrose se bekering in Jona 1:16 het sy parallel in die Nineviete se gelowige optrede in Jona 3:5. Dit is merkwaardig dat in sowel Jona $1: 16$ as 3:5 die reaksie deur drie handelinge uitgebeeld word wat tot God gerig is;

* albei die helftes bevat vervolgens 'n gebed van Jona, naamlik Jona 2:3-10 en 4:2-3;

* albei die gedeeltes sluit af met wat Licht (1978:122) noem 'the two didactic miracles of the fish and the plant' (Jona 2:1-11 \& 4:6-11);

* albei die gedeeltes se belangeruimtes stem ook ooreen met die roepingsepisodes in Jona 1:1-3 en 3:1-3 wat in Israel afspeel. Daarby korrespondeer die gebeure in die eerste helfte waar dit eers binne en daarna buite die skip afspeel, met die gebeure wat in die tweede helfte eers binne en daarna buite die stad plaasvind. 
Herhaling op die narratiewe vlak, binne die teks self, is dus belangriker as die herhaling van die storiegebeure wanneer ' $n$ bepaalde gebeure meer as een keer vertel word.

Repetisie word egter ook gebruik om verbande op die mikrovlak van die teks tussen gebeure binne episodes en tussen episodes onderling te bewerkstellig. Magonet (1976:13-38) het op uitgebreide wyse die verskynsel van repetisie in Jona bespreek. Hoewel hy hierdie saak baie deeglik ondersoek het, is daar 'n paar onnoukeurighede en gebreke in sy bespreking. So vermeld hy wanneer hy in sy skema oor ירא 'vrees' ses maal voorkom, maar die verbale vorm kom slegs vier maal voor, terwyl die infinitief die ander twee maal as substantief gebruik word. Daarby werk hy met die 'primary meaning' (Magonet 1976:26) van die werkwoord קרא 'uitroep' wat volgens die moderne leksikografie nie houdbaar is nie (Wendland \& Nida 1985:2-3). Hiervolgens word woorde se betekenis deur hulle konteks bepaal en het ' $n$ woord dus nie 'n 'primary meaning' of 'n 'Grundbedeutung' nie. Verder konsentreer hy op die patroonmatige funksies van die herhalings sonder om eers oor die omvang van die eenhede te besin, met ander woorde of dit 'n sleutelwoord, 'n tema of 'n gebeure-reeks is. Hierdie funksies wat hy 'comparison and contrast' (Magonet 1976:19) en 'multiple meanings' (Magonet 1976:22) noem, word ook nie volgens 'n narratologiese model in relasie tot die struktuur of tot karakterisering of die tydsaspek bespreek nie. Ten spyte van hierdie gebreke, bly die werk wat Magonet so gedetailleerd gedoen het, waardevol en is dit sinneloos om alles hier te herhaal. Daarom sal slegs een voorbeeld van elke kategorie volgens Alter se model waar dit wel voorkom, bespreek word en terselfdertyd sal Sternberg se drie asverhoudings ook geïmplementeer word.

Wat uniek in Jona is, soos wat uit die volgende analise sal blyk, is dat selfs groter eenhede altyd rondom Leitwörter herhaal.

Die volgende repetisietipes kan in Jona geïdentifiseer word:

1) Herhalings van 'n enkele Leitwort:

(a) Die heel eenvoudigste vorm van repetisie word in Jona 1:7 met die werkwoord נפל 'die werp van die lot' uitgevoer. Alhoewel die herhaling 'n tegniese handeling uitbeeld, beïnvloed dit nie die gang van die verhaal nie, maar illustreer dit die drieledige samestelling van repetisie baie duidelik (Sternberg 1985:376):

The member of forecast.

- Kom laat ons die lot werp; 
(ii)

(iii)
The member of enactment.

The member of report.
- en hulle het die lot gewerp;

- en die lot het op Jona geval.

(b) 'n Meer gesofistikeerde vorm van die herhaling van 'n Leitwort word deur middel van die werkwoord טרו 'werp' in Jona 1 uitgebeeld. Hierdie werkwoord word vier maal, naamlik in Jona 1:4, 1:5, 1:12 en 1:15 herhaal. In Jona 1:4 werp Jahwe die wind op die see en in 1:5 werp die matrose die vrag van die skip oorboord. In Jona 1:12 sê Jona die matrose aan om hom oorboord te gooi, en wanneer hulle aan sy versoek voldoen in 1:15, klaar die storm op. So word hierdie hele episode gekonstrueer deur middel van die herhaling van die Leitwort טרול. Die episode begin dus met Jahwe se werp van die wind op die see en die gevolglike storm en eindig met die kalmte van die see nadat Jona in die see gewerp is. Alhoewel dit opmerklik is dat Jahwe se optrede die direkte oorsaak van die drie ander gebeure is, tree dit tesame met die volgende twee op as 'forecasting', terwyl die oorboord gooi van Jona die 'enactment' is. By die laaste twee herhalings funksioneer Sternberg se asse van die objek en van ekwivalensie, as Jona se versoek in die direkte rede weergegee word, terwyl die voltrekking indirek sonder variasie gerapporteer word.

2) Motief: Hiermee word 'n sensoriese kwaliteit of 'n konkrete beeld wat herhaaldelik voorkom, uitgebeeld. Die werkwoord ירד 'afdaal' kom drie maal (Jona $1: 3,1: 3,1: 5)$ in die eerste twee episodes en een maal (Jona 2:7) in die gebed van Jona voor. Daarmee word die dalende tendens in Jona se bewegings aangetoon wat begin met sy afgaan na die hawestad Joppe, gevolg deur sy afgaan op die skip en daarna sy afgaan in die skeepsruim, totdat dit 'n klimaks in die gebed bereik waar hy tot by die fondasies van die berge afdaal. Daarmee word op metaforiese wyse gesê dat hy tot by die laagste punt - die doderyk - afgedaal het. Met die herhaling van hierdie werkwoord word vier episodes aan mekaar verbind om ' $n$ eenheid van Jona se fisiese afdaling, of nog beter, agteruitgang tot by sy laagtepunt uit te beeld. Hierdie negatiewe bewegingslyn is des te meer opvallend as daarop gelet word dat dit volgens die as van die objek die eerste drie maal in die derde persoon vertel word en die laaste maal in die eerste persoon in die direkte rede. Sodoende word daar volgens die as van ekwivalensie variasie teweeggebring waarmee die klimaks van die afdaal bevestig word veral as 
die antoniem van afdaal, naamlik עלה 'optrek uit die doderyk' (Jona 2:7) direk daarna gebruik word.

3) Tema: Hiermee word ' $n$ idee - moreel of teologies - wat deel is van die waardesisteem van die verhaal, deur' $n$ herhalende patroon uitgebeeld. Die frase $x^{\prime}$ ? נאברד 'sodat ons tog nie omkom nie' word drie maal (Jona 1:6, 1:14, 3:9) as 'n versugting geuiter. Telkens vorm dit deel van 'n uitgebreide wensbede, eers deur die kaptein van die skip, daarna deur die matrose en laastens deur die koning van Nineve. Hierdie teologiese idee van die behoud van menselewens speel so 'n belangrike rol in die verhaal dat dit in elke episode voorkom. Selfs in die twee episodes waar Jona geroep word, naamlik Jona 1:1-3 en 3:1-3, is die bedreiging van die lewens van Nineve se mense latent teenwoordig en word dit eers in Jona 3:4 met sy preek eksplisiet gestel. Op die skip is daar gedurende die storm ' $n$ wesenlike gevaar van lewensverlies. Die episode sluit juis met die dankbare reaksie van die bemanning af wanneer hulle lewens gespaar word. Selfs Jona se gebed in die vis sentreer rondom sy onverwagte verlossing van die bedreiging van die dood. Trouens, hierdie hele gebed beweeg tussen die twee pole van nood en verlossing met die klem op die verlossing in die laaste reël wat die klimaks en afsluiting vorm. In die episode binne Nineve bereik die bedreiging van menselewens 'n hoogtepunt met die preek van Jona. Die dringendheid van die koning van Nineve se wens kry reliëf teen hierdie agtergrond. Tog is dit eers met Jona se doodswens in Jona 4:3, 4:8 en 4:9 en die daaropvolgende antwoord van God in Jona 4:10-11 dat hierdie wens om die behoud van die lewe werklik as teologiese idee in sy volle betekenis verstaan kan word.

Al drie bedewense word in die direkte rede en dus verbatim weergegee en daarmee word die as van ekwivalensie geaktiveer. Twee van hierdie wense, naamlik dié van die kaptein en dié van die koning het min of meer dieselfde strekking en is per se op selfbehoud gerig, terwyl die matrose nie selfbehoud ten koste van iemand anders se lewe wil laat geskied nie. Dit lyk dus of die as van motivering hiermee geaktiveer word. Die variante weergawe van die matrose se versoek sowel in woord as in gees, is doelbewus om as kontras vir Jona se latere optrede te dien.

4) Gebeurereeks: Hieronder word verstaan dat 'n bepaalde gebeurtenis drie maal of drie plus een maal herhaal kan word. Gewoonlik word die reeks op so 'n wyse aangebied dat daar tussen die verskillende herhalings intensivering is. Deur middel van kleinere toevoegings of weglatings werk die herhaling op tot of 'n klimaks of 'n omkering van die betekenis. 
(a) Die voorbeeld wat in Jona bespreek gaan word, het betrekking op God se beskikking van die wondergebeure in Jona $2: 1,4: 6,4: 7$ en 4:8. Vir die beskikking van hierdie wondergebeure word die Pi'el Imperfektum derde manlik enkelvoudvorm van die werkwoord מנה gebruik. Die normale volgorde van drie plus een waarin sulke gebeurereekse voorkom, word egter in Jona omgekeer na een plus drie. Behalwe die volgorde is die plek van hierdie gebeure binne die opbou van die verhaal, asook die aard daarvan belangrik om die verhaal te verstaan. Wondergebeure soos die beskikking van ' $n$ vis, of ' $n$ boompie, of ' $n$ insek, of ' $n$ wind, is deel van die konvensie van volksverhale en ook van ideologiese literatuur soos godsdienstige verhale. Die hoorders of lesers van hierdie verhale betwyfel nie sulke gebeure nie, maar aanvaar dit as deel van die genrekonvensie. Dit is interessant om op die plasing en die volgorde van hierdie wondergebeure binne die totaalstruktuur van die verhaal te let. Al vier gevalle het die profeet as objek van die gebeure. In Jona 2:1 is die beskikking van die vis 'n positiewe gebeurtenis vir die profeet en hy respondeer gunstig daarteenoor. In Jona 4:6 is die beskikking van die boompie daarop gemik om die profeet letterlik en figuurlik af te koel waarop hy met groot vreugde reageer. Daarna beskik Jahwe in Jona 4:7'n wurm om die boompie te steek sodat dit verdroog. Hierdie negatiewe beskikking word nog verder gevoer as God daarby die Oostewind, die gloeiende woestynwind, beskik om saam met die son Jona tot oorgawe te dwing. Jona reageer dan ook inderdaad met 'n wens om te sterf. Hierdie laaste drie beskikkings in Jona 4 vorm 'n triade wat gesamentlik teenoor die wondergebeure in Jona 2 staan. Binne die triade is daar ' $n$ ontwikkelingsgang van positief na negatief, van groot blydskap tot 'n doodswens. Die positiewe gesindheid wat die wondergebeure in Jona 2:1 ontlok, het dus ' $n$ teenpool in die negatiewe reaksie wat die gebeure in Jona 4:8-9 tot gevolg het. Dit is dan ook by hierdie pessimistiese stemming waarby God 'n aanknopingspunt vind vir sy slotrede in Jona 4:10-11.

Magonet (1976:33-38) wys verder op die interessante wisseling van die Godsname in die boek wat ook in hierdie reeks van wondergebeure gereflekteer word. Alhoewel die eienaam Jahwe in die eerste drie hoofstukke dominant gebruik word vir die God van Israel, die Almagtige, word 'n ander sisteem in hoofstuk 4 gevolg. In hierdie hoofstuk word genade en barmhartigheid met die naam Jahwe geassosieer, terwyl dissipline en tugtiging weer met Elohim/Ha-Elohim in verband gebring word. Dit blyk duidelik uit watter name as subjekte vir die wondergebeure gekies word. In Jona 2:1 is Jahwe die subjek van ני? J en in Jona 4:6 is Jahwe in kombinasie met 
Elohim die subjek. Beide hierdie gevalle illustreer God se genadige beskikking teenoor sy weerbarstige profeet. Daarenteen is Elohim die subjek van die beskikking van sowel die wurm as die Oostewind en dit is ook Elohim wat daarna vir Jona vra of hy rede het om kwaad te wees (Jona 4:9). Maar sodra $07 \pi$ 'genade' ter sprake kom, is dit weer Jahwe wat die subjek is (Jona 4:10-11). Wat is die funksie van die viervoudige herhaling van hierdie wondergebeure? Aangesien dit deur die verteller met belangrike wysigings vertel word, kom die asse van ekwivalensie en motivering ter sprake. Die eerste funksie is struktureel van aard. Omdat die wondergebeure op presies dieselfde plekke in die twee helftes van die boek voorkom, naamlik ná die positiewe reaksies van die heidene teenoor God, geld dit as 'n samebindende krag in die boek. Tweedens word die omkering in Jona se gesindheid en die onredelikheid van sy optrede daarmee gedemonstreer. Hierdie omkering is juis een van die belangrikste funksies van hierdie gebeurereekse. Laastens illustreer hierdie gebeure dat alhoewel verskillende name vir God gebruik word, dit dieselfde handelende God is wat genade in oorvloed kan betoon, maar ook kan tug as dit nodig is. Daarmee word die belydenis van die matrose in Jona $1: 14$, 'Want $U$ is Jahwe - $U$ doen soos wat $U$ goed dink' beklemtoon.

5) Toneeltipe: Met hierdie vertaling van Alter se 'type-scene' word die herhaling van 'n hele episode bedoel. So 'n geykte toneel reflekteer 'n beslissende moment in 'n akteur se lewe en bestaan uit 'n aantal motiewe wat in 'n vaste volgorde voorkom.

(a) Die toneeltipe wat in Jona herhaal word, is die profetiese roeping. Voorbeelde van hierdie toneeltipe kan gevind word in 1 Konings 17:8-10, Jesaja 6:1-9, Jeremia 2:1-2, Esegiël 2:1-7, Hosea 1:1-3 en Amos 7:12-15. Drie vaste motiewe kan in al hierdie voorbeelde teruggevind word. Behalwe dat hulle in ' $n$ vaste volgorde voorkom, word hierdie motiewe ook in min of meer vaste formules uitgedruk.

I) In die eerste motief kom die roeping van die profeet ter sprake wat uit drie elemente bestaan:

(i) die subjek van die roeping wat in die frase 'die woorde van Jahwe het gekom tot' as Jahwe aangedui word; 
(ii) die objek van die roeping waar die profeet se volle naam gegee word, byvoorbeeld Jesaja, die seun van Amos;

(iii) die tyd waarin hierdie roeping tot die profeet gekom het wat gewoonlik deur die regeringstye van spesifieke konings aangedui word, byvoorbeeld 'in die dae van Ussia, Jotam, Agas en Hiskia, die konings van Juda'.

II) In die tweede motief word die opdrag meestal deur kombinasies van bepaalde werkwoorde in die bevelsvorm gegee. Hierdie opdrag betaan dikwels ook uit twee elemente, naamlik:

(i) 'n opdrag om te gaan met werkwoorde soos Diר 'staan op' en ר? 'gaan' wat gebruik word;

(ii) 'n opdrag om te praat of te preek met werkwoorde soos קרא en רבר.

III) In die derde motief word die voltrekking van die opdrag uitgebeeld. Dit word gedoen deur of direk met die boodskap, met of sonder die boodskappersformule כדה אָמר יָזנד, voort te gaan, df eers te rapporteer dat die profeet gereed gemaak en toe gegaan het en daarna die boodskap gelewer het. Soms, soos by Elia (1 Konings 19:13-21) en by Jeremia (Jeremia 1:6-8) kan daar besware of 'n vertraging wees voordat die opdrag uitgevoer word.

Hierdie toneeltipe van die profetiese roeping word twee maal in Jona herhaal, naamlik in Jona 1:1-3 en 3:1-4. In Jona 1:1-3 ontbreek daar elemente in sowel die eerste as die derde motiewe. In die eerste motief ontbreek die derde element waarin die spesifieke tyd van die profeet se roeping in terme van die regeringsjare van 'n bepaalde koning weergegee word. Hierdie weglating is doelbewus, omdat 'n mens hier nie met die profetiese genre te doen het nie, maar met 'n verhaal waarin die vaagheid funsioneel in diens van die verhaal staan om fiktiewe afstand te skep. Wat die derde motief betref, begin die gedeelte oën-

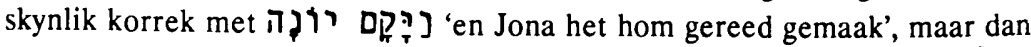

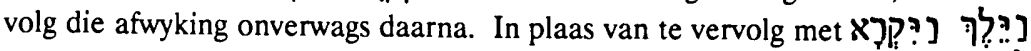

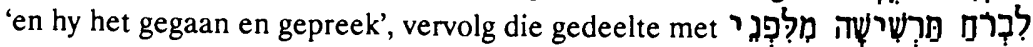
יְנוך 'om na Tarsis, weg van die opdrag van Jahwe, te vlug'. Lohfink (1961:200) wys daarop dat hierdie feit beklemtoon word deur die volgende konsentriese opbou van vers 3 : 
A Maar Jona het hom gereed gemaak om na Tarsis, weg van die opdrag van Jahwe, te vlug;

B en hy het afgegaan na Joppe;

C en hy het daar 'n skip gevind wat na Tarsis toe gaan;

C' en hy het die reisgeld betaal;

B' en hy het daarin afgegaan;

$A^{\prime}$ om saam met hulle na Tarsis, weg van die opdrag van Jahwe, te gaan.

Hieruit konkludeer Lohfink (1961:200): 'Die Form [A+B + C + Zentrum $\left.+C^{\prime}+B^{\prime}+A^{\prime}\right]$ ist hier durch Wort und Motiverepetitionen herausgearbeitet.' Drie maal word dus gesê dat hy na Tarsis toe gaan en twee maal dat hy van die aangesig van Jahwe wegvlug. Tereg meen Van der Woude (1978a:20) dat Jona se wegvlug 'n ontwyking van sy opdrag is en nie 'n wegvlug van Jahwe is nie.

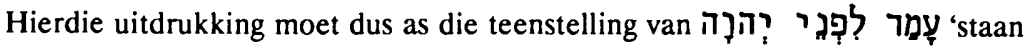
voor Jahwe' wat op ampsaanvaarding of ampsuitoefening dui, gesien word (1 Kon 17:1; Jer 15:19). Wanneer hierdie profetiese roeping in Jona 3:1-4 herhaal word, geskied dit met interessante wysigings. Omdat die profeet nou by die hoorder of leser bekend is, word sy volle naam nie herhaal nie, maar word die בדן ge gedeelte weggelaat. Verder word uitdruklik vermeld dat hierdie roeping nou 'n tweede keer' tot Jona kom. Daarmee word op 'n pregnante wyse God se genade om Jona 'n tweede kans te gee, geilllustreer. Ander ongehoorsame profete soos dié een in 1 Konings 13 was nie so gelukkig om 'n tweede kans te kry nie (Allen 1976:220).

Ook wat die tweede motief betref, verskil Jona 3:2 van 1:2. Die eerste verskil lê in die gebruik van die preposisies saam met word. Alhoewel Wolff (1977:114-118) uit die preposisiewisseling 'n verskil in betekenis wil aflei, wys Van der Woude (1978:44) tereg daarop dat hierdie preposisies se gebruik in latere Hebreeus nie so noukeurig van mekaar onderskei kan word nie. Tweedens verskil Jona 1:2 en 3:2 van mekaar daarin dat die motivering van die prediking in Jona 1:2 'want haar boosheid het tot by My opgekom' vervang word met 'die boodskap wat Ek aan jou opdra'. Ná die geskiedenis wat op die eerste roeping gevolg het, is dit onnodig om die motivering te herhaal. Die boodskap self is nou van belang en daarom vervang dit die motivering. Tog word die presiese bewoording van die boodskap nog nie in hierdie stadium van 'prolepsis' (Genette 1980:40) gegee nie, maar word dit uitgestel om die spanningslyn te laat styg.

Met die nakoming van die opdrag in Jona 3:3 verloop die derde motief hierdie keer sonder haakplek. Die profeet maak hom klaar en gaan na Nineve vol- 
gens Jahwe se woord. Steeds hoor 'n mens nie die boodskap nie en word die spanning nog verder verhoog. Nou word eers nog 'n maal op die grootte van Nineve gekonsentreer voordat die boodskap in Jona 3:4 kort en kragtig in net vyf Hebreeuse woorde weergegee word. Behalwe die motiewe wat in vaste volgorde makaar opvolg, word twee stelle opvallende Leitwörter in die strukturering van hierdie herhalende toneeltipe gebruik. Die eerste Leitwort is 'preek' wat in Jona 1:2, 3:2 (2x) en 3:4 herhaal word. Alhoewel die werkwoord קרא drie maal en die naamwoord een maal genoem word, word die inhoud slegs een keer eksplisiet weergegee. In Jona 1:2 word net die opdrag om te preek gegee, terwyl in 3:2 die opdrag herhaal word, maar dit word nader gespesifiseer as 'die preek wat Ek jou sal gee'. Dan lewer Jona in Jona 3:4 die preek en word die inhoud uiteindelik bekend. Hiermee word die effek van 'Steigerung' bereik. Dit laat Licht (1978:58) konkludeer:

The author could have made his point even clearer by revealing the burden of the prophetic message as soon as he mentions it for the first time, and again, at the second mention. He has preferred not to do so, and thus to achieve an effect of slight mystery at the beginning and its resolution as the story proceeds. Thematic and structural clarity, and a well-established pattern, have been rejected to gain an aesthetic effect of a different kind - the effect of suspense.

Alhoewel ek van Licht verskil oor die tematiese en strukturele duidelikheid, stem ek wel saam dat deur hierdie stilistiese konvensie spanning tot stand gebring word. Licht se probleem is dat hy na die herhaling van sekere woorde in isolasie gekyk het en nie hoe dit ook in groter patrone voorkom juis om tematies en strukturele eenheid te bewerkstellig nie. Hierdie groter patrone wat deur herhaling tot stand kom, het nie alleen implikasies vir die tematiese en strukturele eenheid van die boek nie, maar ook vir karakterisering en die ontwikkeling van die intrige. Juis deur hierdie groter patrone met mekaar te vergelyk en te kontrasteer, word belangrike inligting ten opsigte van die karakterisering en die intrige van die verhaal bekom.

In die beskrywing van Nineve as die groot stad (wat vier maal herhaal word), kom die tweede stel Leitwörter voor. In Jona 1:2 en 3:2 word slegs gesê

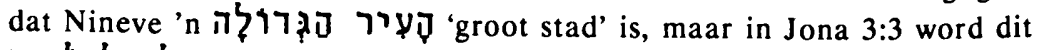
"n ontsaglike groot stad' genoem. Dit is om 't ewe of ליאלדים as 'n superlatief 'ontsaglik groot' of as 'n bywoordelike frase 'volgens God se standaarde' gesien word. Die effek is dieselfde aangesien dit saam met die daaropvolgende beskrywing van 'drie dagreise' gelees moet word. Hierdie 
beskrywing werk klimakties op na Jona 4:11 waar die grootte van Nineve in terme van sy onkundige inwoners se getal uitgedruk word. Wat merkwaardig van hierdie stel herhalings is, is die feit dat dit vergestalt word deur middel van 'the growing phrase' wat hier onder by punt 6 in meer besonderhede bespreek sal word.

6) Spesifieke frases wat deur toevoeging van 'n woord of woorde uitgebou word: Hiermee word 'the growing phrase' onder die loep geneem wat Magonet (1976: 31) soos volg definieer: 'The repetition of an identical phrase after an interval enables us to examine the same events in a new way, in the light of the intervening experience.' Benewens die geval van Nineve, die groot stad, wat reeds genoem is, word twee addisionele gevalle van hierdie verskynsel wat van kardinale belang vir die verstaan van die boek is, bespreek. Hierdie twee gevalle kom naamlik in die eerste en laaste hoofstukke van die verhaal voor.

* Die eerste frase wat op hierdie manier herhaal word, het betrekking op die vrees van die matrose. Drie maal (Jona 1:5, 10 \& 16) word hierdie frase telkens met ' $n$ toevoeging herhaal sodat ' $n$ mens van 'n tricolon crescens sou kon praat. In Jona 1:5 word die vrees van die matrose as reaksie op die storm en die skip wat op die punt was om te vergaan, net bloot genoem. In Jona 1:10 word hulle reaksie op die belydenis van Jona geïntensiveer deur te sê dat hulle 'grootliks gevrees' het. Die klimaks van hierdie vrees word bereik in Jona 1:16 met die woorde 'die manne het Jahwe grootliks gevrees' wat as 'n reaksie kom op die kalmte van die see nadat hulle Jona oorboord gegooi het. Magonet (1976:32) wys daarop dat die manne se vrees met hulle verlossing van die dood in Jona 1:16 groter is as toe hulle deur die dood in Jona 1:5 bedreig is. Alhoewel hierdie toevoegings in die verlede as verklarende glosses afgemaak is, is daar 'n besliste narratiewe funksie in die herhaling van hierdie frases te bespeur. Nie alleen dra dit by om die spanning te verhoog nie, maar dit speel ook 'n besliste rol in karakterisering. Dit sal veral duidelik word wanneer hierdie voorbeeld met die volgende voorbeeld wat bespreek sal word, vergelyk word.

* In beide Jona 4:3-4 èn 8-9 word Jona se begeerte om te sterf opgevolg deur 'n vraag van Jahwe of hy rede het om kwaad te wees. In vers 9 word die woorde על-כקיקיקיו 'oor die boompie' bygevoeg. Jona se antwoord hierop as die derde lid van die tricolon crescens is 'n kombinasie van Jahwe en Jona se eie woorde. In Jona se antwoord word die verwysing na die boompie weggelaat, maar die element wat bygevoeg word, is te vinde in die antoniem van wees' naamlik חרenadig wees' waarmee Jahwe Jona in verse 10 en 11 konfronteer. Hiermee word 'n nuwe dimensie aan hierdie tipe frase verleen as dit 
net soos by gebeurereekse in 'n drie plus een patroon herhaal word. 'n Verdere ooreenkoms met gebeurereekse is dat die laaste lid 'n omkering in die betekenis van die voorafgaande lede bewerkstellig. Op hierdie manier word van Jona se ontevredenheid oor Nineve se redding na sy ontevredenheid oor sy eie ongemak beweeg. Sodoende word ' $n$ ironiese vergelyking tussen hierdie twee ontevredenhede getref. Die ironie blyk des te duideliker wanneer Jona se reaksie van woede en 'n wens om te sterf met die voorafgaande reaksie van vrees en ontsag van die heidense matrose vergelyk word. Hierbo is op die wye verskeidenheid gewys waarop repetisie in die boek Jona gebruik word. Benewens die estetiese funksie word 'n patroonmatigheid daargestel wat in diens van die betekenis staan. 'n Netwerk van relasies wat die blote noodsaak van konvensie te bowe gaan, word daardeur tot stand gebring. Hierdie relasies is nie beperk tot die makrostruktuur van die boek nie, maar geld ook tussen alle narratiewe aspekte in die mikrostruktuur van die verhaal.

\subsection{Karakterisering}

Sowel Rimmon-Kenan (1983:31-36) as Brink (1987:66-67) wys op die problematiek, enersyds of karakters mense of blote woorde is en andersyds, of karakters ondergeskik aan die gebeure is al dan nie. Aangesien hierdie polemiek 'n mynveld kan wees, moet dit liefs vermy word en daarom is dit wys om soos Rimmon-Kenan en Brink vir ' $n$ alternatief te kies. Die alternatief is daarin geleë om 'karakters te beskou as iets wat ontstaan uit - en bestaan by - die wisselwerking tussen al drie die wêrelde van 'n verhaal [storie, vertelteks, vertelproses], en tussen al die gegewens, impulse, elemente of aspekte binne daardie hele kompleks' (Brink 1987:67). Binne die konteks van hierdie hoofstuk word karakterisering egter as relasie tussen die storievlak en die diskoers behandel (Rimmon-Kenan 1983:33). Om daaraan te voldoen word die skema van narratiewe makrosemantiek van Dolozel (1979:203) as uitgangspunt gebruik. In hierdie skema word karakterisering as funksies tussen die drie wêrelde van die verhaal, naamlik die primêre en die sekondêre wêreld, wat saam die ekstensionele wêreld vorm, en die intensionele wêreld uitgebeeld. Die individualiserende funksie is binêr tussen die sekondêre en die primêre wêreld, terwyl die intensionele funksie tweeledig tussen die primêre wêreld geëvalueer word. Hierdie skema sien so daaruit: 
Ekstensionele wêreld

Sekondêre wêreld

Individualiserende funksie

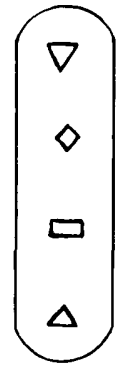

Intensionele wêreld

Primêre wêreld

Intensionele

funksie

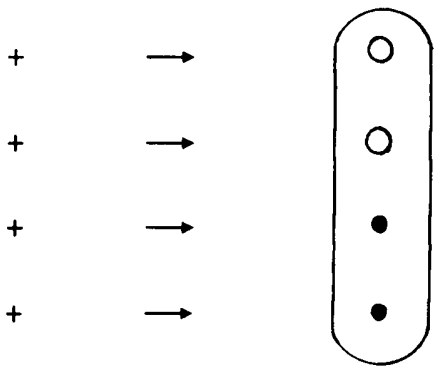

In terme van Genette se model sal die ekstensionele wêreld met die storievlak ooreenstem terwyl die intensionele wêreld met die verhaal sal ooreenstem. Volgens hierdie skema kan die primêre narratiewe wêreld gedefinieer word as 'a set of compossible narrative agents' (Dolozel 1979:196). Hierdie agente word beskryf deur twee eienskappe, naamlik deur die 'enumerability of its members' en 'their independence of designation'.

\subsubsection{Sekondêre narratiewe wêreld}

Deur middel van die individualiserende funksie word hierdie agente van die primêre narratiewe wêreld in die sekondêre narratiewe wêreld aktante genoem wat gedefinieer kan word as 'n 'klas akteurs wat 'n gemeenskaplike kenmerk vertoon' (Gräbe 1985:18). Volgens Greimas sal die gemeenskaplike kenmerke wat 'n aktant vertoon, saamhang met die doel wat in die storie nagestreef word. Die getal aktante in Greimas se aktansiële model word tot die volgende ses beperk (Rimmon-Kenan 1983:35):

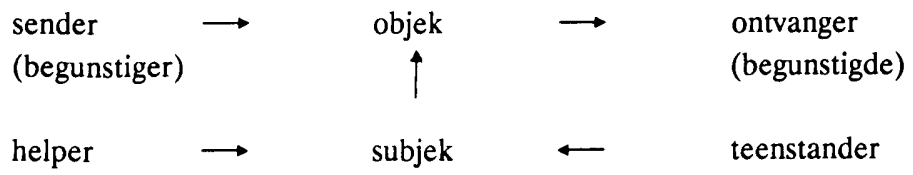

In Jona kan hierdie aktansiële model soos volg toegepas word: Op die eerste as, naamlik van die subjek en die objek, strewe die subjek na 'n bepaalde doel wat deur 
die objek vergestalt word. Jahwe figureer in Jona as die subjek en sy strewe om as die vrymagtige God erken te word, as die objek. Daarmee neem die boek 'n aanvang wanneer Jona in Jona 1:1-3 'n opdrag ontvang om teen Nineve te gaan preek met dié motivering 'want hulle boosheid het tot voor my aangesig gekom'. Hierdie vrymagtigheid van God loop soos 'n goue draad deur die hele verhaal wanneer dit deur die kaptein van die skip in Jona 1:6 en deur die koning van Nineve in Jona 3:9 geïmpliseer word. Maar dit word eksplisiet deur die matrose in hulle gebed in Jona 1:14 in die volgende woorde uitgedruk: ' $W$ ant $U$ is Jahwe $-U$ doen soos wat $U$ goed dink.' Hierby sluit Jahwe self aan in Jona 4:10-11 wanneer hy op ironiese wyse hierdie vrymag deur sy retoriese vraag aan Jona demonstreer.

Op die as van die begunstiger en die begunstigde tree Jahwe as begunstiger op terwyl daar verskillende begunstigdes in die loop van die verhaal voorkom. In die eerste plek word Jahwe self deur sy strewe begunstig wanneer Hy deur mense op 'n wyse vereer word soos wat $H y$ dit verkies. Verder is die heidene wat deur die matrose en die mense van Nineve in die boek verteenwoordig word, voorwerpe van God se begunstiging. Dit blyk uit die redding van die matrose en hulle reaksie in Jona 1:15-16, asook uit God se begenadiging van die mense van Nineve in Jona 3:10. Laastens is Jona die eintlike voorwerp van Jahwe se strewe en dus ook van sy begunstiging soos blyk uit die episodes wat betrekking het op die vis, die tweede roeping, die boompie en veral God se finale gesprek met Jona. Hierdie gesprek eindig met ' $n$ vraag aan Jona waarop hy geen antwoord gee nie. Sy antwoord (en die leser se antwoord) word slegs geïmpliseer, maar die implikasie is dat hy Jahwe se strewe aanvaar en daarom daardeur bevoordeel word.

Die derde as word verteenwoordig deur die twee pole, helper en opponent. Waar die helper die subjek bystaan om sy strewe te verwesenlik, tree die opponent op so 'n wyse op dat hy struikelblokke in die subjek se pad plaas. In Jona kan daar 'n onderskeid tussen die menslike helpers en die nie-menslike helpers getref word. Met laasgenoemde word na die storm, die vis, die boompie, die wurm en die Oostewind verwys. Behalwe die storm wat primêr op Jona gerig is, maar tog die matrose ook tref, is al die ander nie-menslike helpers se funksie om God se doel met Jona te bereik. Alhoewel die matrose aanvanklik as opponente van Jahwe optree omdat hulle vir Jona help om van sy opdrag af weg te vlug, verander hulle funksie in Jona 1:14 tot helpers wanneer hulle Jona onvermydelik in die see moet gooi. Die vernaamste opponent van Jahwe vanaf die aanvang van die verhaal tot aan die einde daarvan is Jona. Sy teenstand teenoor Jahwe se strewe begin met sy ongehoorsaamheid aan die opdrag om na Nineve te gaan. Hy weier om as uitverkore helper - as profeet - op te tree, deur te probeer wegvlug van sy opdrag. Daardeur verhinder hy die strewe van die subjek en moet ander helpers ingespan word om die doel te ver- 
wesenlik. In die eerste helfte van die boek, hoofstuk 1-2, is hierdie weerstand fisies van aard. Oënskynlik is hy in die tweede deel van die boek, hoofstuk 3-4, gehoorsaam en verander sy aktansiële rol van teenstander na helper. Dit is egter slegs oënskynlik, want eintlik verander sy weerstand net van die fisiese na die psigiese vlak soos blyk uit sy woede oor Jahwe se besluit in Jona 4:1. Daaruit is dit duidelik dat hy nog nie werklik Jahwe se besluit aanvaar het nie. In Jona 4:2 motiveer hy hierdie teenstand deur 'n persepsie wat ironies genoeg in ooreenstemming met Jahwe se strewe blyk te wees. Eers as hy fisies in so 'n posisie kom dat hy wil versmag (Jona $4: 8$ ), is sy geestestoestand ook van so 'n aard dat hy moet luister na en toegee aan Jahwe. Hoewel die afloop tegnies oopgelaat word, word aan die einde tog geïmpliseer dat Jona se aktansiële rol van teenstander tot helper en daarmee ook saam tot begunstigde verander het. Indien dit nie so aanvaar word nie, beteken dit dat die subjek se strewe nie gerealiseer het nie. In die lig van die profetiese perspektief waaruit hierdie verhaal vertel word, sou dit uiters onaanvaarbaar wees.

Dit is opmerklik dat in die boek Jona verskeie aktansiële rolle deur dieselfde akteur vervul word; anders gestel, een akteur beklee tegelykertyd verskillende rolle of verander van rol gedurende die loop van die verhaal. So is Jahwe tegelyk subjek, begunstiger en begunstigde terwyl die matrose eers opponente en daarna helpers en uiteindelik begunstigdes word. Jona is opponent, maar word helper, eers net ten dele, maar by implikasie uiteindelik ten volle. By verskeie geleenthede is hy begunstigde, maar eers aan die einde van die verhaal, wanneer hy help om Jahwe se strewe te realiseer, word hy werklik begunstigde in die ware sin van die woord.

Uit bogenoemde klassifisering van die akteurs in terme van hulle funksie in die verhaal het dieselfde opmerking wat Gräbe (1986:273) ten opsigte van die gelykenis van die barmhartige Samaritaan gemaak het, op Jona betrekking. Ook in Jona vind daar 'n omkering van sosiale rolle plaas. Die heidene as vreemdelinge tree teen die verwagting in as helpers van die subjek op om sy strewe te verwesenlik. Daarenteen tree Jona, die profeet, ook teen sy rolverwagting van die veronderstelde helper op wanneer hy die strewe van die subjek opponeer.

Hoewel terme soos 'antagonis' en 'protagonis' nie binne die konteks van Greimas se aktansiële model voorkom nie, is dit miskien tog van pas om in hierdie stadium na aanleiding van die aktansiële rolle in Jona enkele opmerkings daaroor te maak. Volgens Egri (1960:106) is die protagonis 'the pivotal character' en 'one who takes the lead in any movement or cause...The pivotal character knows what he wants. Without him the story flounders...in fact, there is no story'. Hiervolgens is dit duidelik dat Jahwe die protagonis in die Jonaverhaal is. Veral as die volgende woorde van Egri (1960:106) ook in ag geneem word: 'A pivotal character must not merely desire something. He must want it so badly that he will destroy or be de- 
stroyed in the effort to attain his goal.' Ideologies gesproke stel Jahwe alles in werking om sy strewe te verwesenlik, selfs al moet $\mathrm{Hy}$ in die proses sy ongehoorsame profeet vernietig. As protagonis neem $\mathrm{Hy}$ in alles die inisiatief, maar $\mathrm{Hy}$ bring ook alles tot volvoering volgens sy wil.

Hierteenoor kan die antagonis soos volg gedefinieer word: 'Anyone who opposes the pratogonist is an opponent or antagonist' (Egri 1960:106). Hieraan voldoen Jona volkome, veral as die volgende woorde van Egri (1960:113) daarby gelees word: 'The antagonist in any play is necessarily as strong and, in time, as ruthless as the pivotal character...The wills of conflicting personalities must clash...A novel, play, or any type of writing, really is a crisis from beginning to end growing to its necessary conclusion.' Jona is dus by uitnemendheid die antagonis wat die protagonis met volharding tot aan die einde teenstaan.

\subsubsection{Die intensionele narratiewe wêreld}

Die verhouding tussen die ekstensionele narratiewe wêreld en die intensionele narratiewe wêreld word deur Dolozel (1979:201) soos volg weergegee:

Similarly as the sense of the lower level semantic units is determined by the form of words, phrases and sentences, the sense of the text is determinined by the form of texture. Texture is our term for the 'wording' of the text and it comprises all lower-level units of expression as its constituents...Consequently, the macrotheory of text sense formulates the principles of sense organization in revealing the global regularities of texture.

Hy illustreer hierdie verhouding deur met 'n voorbeeld aan te toon hoe narratiewe agente van die primêre narratiewe wêreld in die intensionele wêreld nader bepaal word. Hierdie spesifisering geskied op twee maniere, naamlik deur eiename en deur spesifieke omskrywings. Dieselfde reëlmatige verspreiding van eiename en spesifieke omskrywings betreffende 'n stel agente wat hy in Defoe se Robinson Crusoe aantoon, is ook op Jona van toepassing. Slegs die primêre agente soos Jahwe en Jona word met eiename in die tekstuur benoem. Daarenteen word die sekondêre agente deur spesifieke omskrywings soos die matrose, die kaptein van die skip, die mense van Nineve en die koning van Nineve getipeer. Dolozel (1979:202) noem hierdie proses waardeur die primêre narratiewe wêreld na sy intensionele korrelaat geprojekteer word, intensionele funksies. As Dolozel se gevolgtrekking dat ' $[t]$ he intensional world and its structure is fully determined by the forms of texture, by the texture regularities expressed in intensional functions' korrek is, kan nou oorgegaan word om die primêre agente van die ekstensionele wêreld in detail in die teks te ondersoek. 


\subsubsection{Karakterisering word om twee redes tot Jahwe en Jona beperk}

* Uit die aktansiële model van Greimas waardeur agente in die sekondêre wêreld as gevolg van hulle rolle geïndividualiseer word, het dit duidelik geblyk dat Jahwe die protagonis en Jona die antagonis is. Die boek Jona is primêr rondom die twee aktansiële rolle opgebou.

* Die 'two-value' intensionele funksie van Dolozel bevestig bogenoemde waarneming dat daar net twee primêre agente is, naamlik Jahwe en Jona wat met eiename benoem is.

* Volgens Hamon se indeling is slegs Jahwe en Jona referensiële karakters, 'dit wil sê karakters wat gerekonstrueer word uit die leser se kennis van die historiese, politieke, sosiale, mitologiese of ander "buitewêreld"' (Brink 1987:69).

Vir die volledige karakterisering van hierdie twee figure word uitgegaan van Dolozel se definiëring van die vertelteks (récit - Genette) (vgl Barkhuizen 1988:56):

$($ VERTEL)TEKS = VERTELLERSTEKS + KARAKTERSTEKS

Hierdie definisie het aanleiding gegee tot De Beus se model wat weer deur Barkhuizen (1988:58) aangepas is. Op my beurt het ek hierdie karakteriseringsmodel soos volg verfyn:

\section{TEKSVLAKKE WAAROP INFORMASIE OOR KARAKTER VOORKOM}

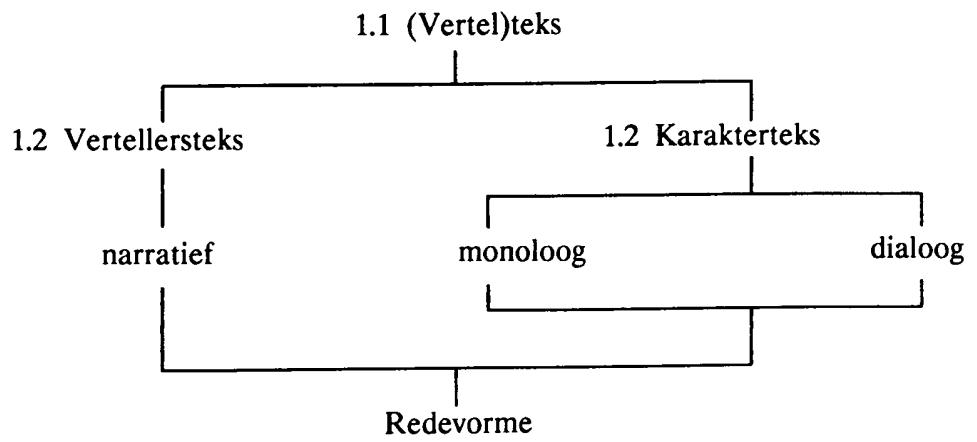

\section{AARD VAN DIE INFORMASIE}

Informasie oor die fisiologiese, psigologiese en sosiologiese dimensies van die figuur word soos volg in die twee bronne van eksplisiete en implisiete informasie vergestalt: 
2.1 Eksplisiete informasie

2.1.1 uit wat die verteller sê

2.1.2 uit wat medekarakter(s) sê en dink

2.1.3 uit wat die karakter oor homself sê
2.2 Implisiete informasie

2.2.1 uit die karakter se optrede

2.2.2 uit die karakter se gesprekke

2.2.3 uit die karakter se voorkoms

2.2.4 uit die karakter se spraakhandeling

\section{WYSES EN TEGNIEKE WAARDEUR INFORMASIE DEURGEGEE WORD}

$\begin{array}{llllll}\text { 3.1 } & \text { Perspektief } & 3.2 & \text { Tegnieke } & 3.3 & \text { Taalhandeling } \\ \text { 3.1.1 } & \text { beskrywend } & 3.2 .1 & \text { benaming } & 3.3 .1 & \text { woordgebruik } \\ \text { 3.1.2 } & \text { ordenend } & 3.2 .2 & \text { herhaling } & 3.3 .2 & \text { sintaksis } \\ \text { 3.1.3 } & \text { evaluerend } & \begin{array}{l}3.2 .3 \\ \end{array} & \text { akkumulasie } & 3.3 .3 & \text { styl } \\ & & 3.2 .4 & \text { transformasie } & \\ & & 3.2 .5 & \text { vergelyking en kontras } & \end{array}$

Die verfyning wat aan Barkhuizen se model aangebring is, berus op die aard van die informasie wat volgens Egri (1960:33) op die volgende wyse toegelig word: 'Human beings have an additional three dimensions: physiology, sociology, psychology. Without a knowledge of these three dimensions we cannot appraise a human being.' Verder word hierdie informasie op twee verskillende maniere, eksplisiet en implisiet soos in 2.1 en 2.2 vergestalt, respektiewelik uiteengesit. 'n Laaste verfyning is die toevoeging van transformasie by die tegnieke waardeur inligting weergegee word. Sowel Egri (1960:212) wat hierdie tegniek 'transition' noem en Brink (1987: 82) wys op die belangrikheid van hierdie tegniek.

\section{A. Die karakterisering van Jona}

Fisiologies word daar sowel eksplisiet as implisiet geen informasie oor Jona gegee nie, behalwe dat hy Jona heet en dat hy manlik is. Laasgenoemde word afgelei uit die werkwoordsvorme wat vir sy optrede in die vertellersteks gebruik word.

Sosiologiese gegewens aangaande Jona dui daarop dat hy die seun van Amittai en 'n profeet van beroep was: dit word uit die toneeltipe van die profetiese roeping in Jona 1:1-3 en 3:1-3 uit die vertellersteks afgelei. Hierdie afleiding word deur die verwysing in 2 Konings 14:25 bevestig wanneer Jona, seun van Amittai, eksplisiet 'n 
profeet genoem word. Hiermee word veronderstel dat dit wel dié Jona van 2 Konings 14:25 is wat as die hoofkarakter van die Jonaverhaal funksioneer. Indien dit die geval is, kan Jona getipeer word as 'n referensiële karakter (Brink 1987:69). Met dié term wat Brink van Hamon ontleen, word bedoel dat 'n karakter '"herken" of gerekonstrueer kan word uit die leser se kennis van die historiese, politieke, sosiale, mitologiese of ander "buitewêreld"'. Die buitewêreld in hierdie geval is dan die konteks van 2 Konings 14:25, waaruit 'n bepaalde voorkennis van Jona deur die leser veronderstel word.

Godsdienstige besonderhede as deel van die sosiologiese gegewens aangaande Jona word deur homself in die karakterteks in 'n dialoog met die matrose in Jona 1:9 verskaf waar hy beweer dat hy Jahwe die God van die hemel, wat die see en die droë grond geskape het, vrees. So erken hy dat Jahwe, die God van Israel, sy God is, maar die omskrywing van hierdie God is taamlik formeel in dié sin dat Hy slegs as Skeppergod geteken word. Dié beskrywing is tipies van die Persiese tydperk en daarom ontbreek daar enige persoonlike verwysing na Jona se verhouding met Jahwe, of na Jahwe se betrokkenheid by die geskiedenis van sy volk en van sy profeet. In antwoord op die matrose se vrae oor Jona se afkoms, gee hy die ietwat vreemde en kriptiese antwoord: 'Ek is 'n Hebreër.' Dit is 'n verwysing na die Israeliete wat in die Ou Testament of deur vreemdelinge of teenoor vreemdelinge soos Egiptenare en Filistyne gebruik is (Van der Woude 1978a:24-25). Hoewel dit hier ook teenoor vreemdelinge gebruik word, dui hierdie gentilicium op meer as net afstamming. Die gevoelswaarde van hierdie frase het ook 'n bepaalde godsdienstige konnotasie omdat dit as bedekte verwysing na ander gedeeltes in die Ou Testament waar dit voorkom, daardie hele denkwêreld oproep.

Voordat daar aan die psigologiese dimensie in detail aandag gegee word, is dit wenslik om die opmerking van Sternberg (1985:327) te beklemtoon: 'In the biblical framework, with its theocentric ideology and ethical concerns and endless situations of choice, the first two sets [physical and social] are definitely subordinate to the last two [moral and ideological as well as psychological]' (my toevoegings). In die beskrywing van die Jonakarakter lê die klem, in ooreenstemming met ander Bybelse verhale, op die psigologiese dimensie. Sowel in die vertellersteks as in die karakterteks kry die leser ' $n$ insae in Jona se gevoelslewe en innerlike gesteldheid.

Eksplisiete informasie oor die geestesgesteldheid van Jona word in die vertellersteks slegs in hoofstuk 4 gegee. Die konflik in Jona se gemoed word uitgebeeld deur die afwisseling van intense woede in Jona 4:1 en groot vreugde in 4:6. Sy intense woede in Jona 4:1, nadat Jahwe Nineve begenadig het, word opgevolg deur 'n gebed om te sterf. Sy woede verander egter in groot vreugde wanneer Jahwe 'n boompie beskik. Hierdie konflik is soveel duideliker wanneer pertinent gesê word 
dat hierdie boompie juis daar gestel word om Jona se woede af te koel. Barkhuizen (1988:59) wat met die Septuaginta-teks werk, beskryf Jona se toestand as 'grootliks bedroef en verward'. Die Hebreeuse teks beskryf hierdie emosie baie sterker as חרכה 'woede': Daarmee word die kontras met die groot vreugde daarna soveel sterker na vore gebring. Jona was beslis ook nie verward nie; daarvoor word hy as die antagonis te sterk geteken. By tye tree hy byna apaties op (Jona 1:11), maar hy is nooit verward nie; daarvoor is sy teenstand teen Jahwe se wens te sterk. In Jona 4:9 verander Jona se groot vreugde in 'n begeerte om te sterf wanneer hy in uiterste fisiese ongemak verkeer. Binne die bestek van slegs nege verse verander die gemoedstoestand van Jona verskeie kere. Eers is hy hoogs ontsteld en bid hy om te sterf - daarna is hy baie bly, maar dit is van korte duur. Laastens, wanneer hy in 'n ondraaglike fisiese toestand verkeer, bereik die konflik in sy gemoed 'n klimaks met 'n finale doodswens.

In die karakterteks word eksplisiete informasie wat deur medekarakters oor Jona verskaf word, tot hoofstuk 1 beperk. Die kaptein is byvoorbeeld verstom dat Jona te midde van die storm kan slaap en nie soos die res van die bemanning om uitkoms bid nie. Hierdie verbasing gee hy in vers 6 met 'n uitroep van '[w]at makeer jou dat jy slaap?' te kenne en spoor hom vervolgens aan om tot sy God te bid. Ook die matrose is in vers 10 geskok oor Jona se optrede en gee dit ook duidelik te kenne met die vraag, 'Wat het jy gedoen?' Trouens, hulle is meer as geskok, hulle is met vrees vervul dat iemand so durf optree. Uit hierdie vrae word die dwaasheid van Jona se optrede aan die kaak gestel. Selfs vir die heidene is hierdie dwaasheid voor die hand liggend, maar die profeet Jona word deur sy onwilligheid om Jahwe te gehoorsaam, gedwing om so op te tree.

Verdere eksplisiete informasie in die karakterteks word deur Jona oor homself in vers 12 gegee wanneer hy 'n skulderkenning teenoor die seelui maak. Met hierdie skulderkenning, 'ek weet dat dit aan my te wyte is dat hierdie groot storm oor julle gekom het' motiveer hy die oplossing wat hy vir die matrose aan die hand doen. Hy voel hom dus moreel verantwoordelik vir die toestand waarin onskuldiges onwetend betrek is. Hoewel daar geen sprake is van emosionele betrokkenheid en dus van psigologiese onstabiliteit in hierdie beslissing van Jona nie, tree hy eties korrek op deur sy eie lewe vir hulle redding op te offer. Dit wat 'n mens van 'n profeet van Jahwe verwag, naamlik gehoorsaamheid en medelye, ontbreek by Jona. Trouens, wat opvallend is, is die byna kliniese onbetrokkenheid waarmee hy in hierdie situasie optree.

Volgens Bal (1980:97-98) word implisiete inligting oor die karakter deur die optrede van die karakter verskaf. Daaruit maak die leser sy eie afleidings oor die aard van die karakter. Twee soorte handelinge moet volgens Bremond van mekaar on- 
derskei word, naamlik waar die karakter as agens optree en waar hy die handeling as patiens ondergaan (vgl Barkhuizen 1988:60). Wanneer Jona van sy opdrag af wegvlug deur 'n skip na Tarsis toe te neem, tree hy as agens op. Daar is reeds op gewys dat die verteller hierdie wegvlug in Jona 1:3 beklemtoon deur dit twee maal, en die bestemming selfs drie maal, te herhaal. Hieruit word nie alleen bepaalde karaktertrekke van Jona duidelik gesuggereer nie, maar sy verhouding met Jahwe word terselfdertyd geskets. Die karaktertrek wat hieruit na vore kom, anders as wat van 'n profeet verwag sou word, is 'n eiesinnigheid wat direk in kontras met Jahwe se strewe staan. Hierdie eiesinnigheid loop uit op ongehoorsaamheid wat noodgedwonge op 'n konfrontasie met Jahwe moet afstuur. Die rede vir hierdie eiesinnige optrede om aan Jahwe se opdrag ongehoorsaam te wees, word egter vir die leser verswyg en eers later (Jona 4:2) bekend gemaak. Sy volgende handeling is om in die ruim van die skip af te gaan en daar te gaan lê en slaap. Alhoewel hy ook in hierdie handeling as agens optree, word dit op so 'n wyse in die teks vertel dat dit lyk asof die diepe slaap oor hom gekom het en hy dus eintlik die patiens van die optrede is. Hierdie optrede versterk die indruk dat Jona in eiesinnigheid sy besluit geneem het en dat hy nou vrede het met die verloop van sake. Alhoewel hy hom deur hierdie blatante ongehoorsaamheid van Jahwe distansieer, voer hy nogtans die handelinge op so 'n wyse uit dat dit van onverskilligheid in die hoogste mate getuig.

In die daaropvolgende twee handelinge is Jona die patiens en is hy die voorwerp van die optrede. So word die lot deur die matrose in vers 7 gewerp en word Jona deur die lot as die oorsaak van die ramp uitgewys. Hy ontken of betwyfel nie die lotsbeslissing nie, maar uit sy saaklike antwoord op hulle vrae, blyk 'n onbetrokkenheid wat byna aan apatie grens. Wanneer hy op sy eie aandrang oorboord gegooi word, aanvaar hy dit ook sonder om vir sy lewe te pleit of om tot Jahwe te bid en sodoende gered te word. In beide gevalle waar hy die voorwerp van die matrose se optrede is, aanvaar hy dit gelate. Hierdie gelatenheid hèt kommentatore in so 'n mate gehinder dat hulle die gebed van Jona waar hy as agens optree, as 'n interpolasie gesien het. Voordat hy hierdie gebed bid, is hy nog 'n maal die voorwerp van 'n handeling. Hierdie keer word hy op Jahwe se bevel deur'n groot vis ingesluk en bly hy drie dae en nagte in die vis se buik voordat hy weer op Jahwe se bevel deur die vis op droë land uitgespoeg word. Dié twee handelinge wat hy as patiens ondergaan, omarm as ' $t$ ware die handeling wat hy as agens in die vis verrig. Daar moet omsigtig te werk gegaan word met die tipering van die Gattung van Jona se gebed, omdat sulke klassifiserings in die verlede, soos wat uit hoofstuk 3 blyk, tot verstaansprobleme van die boek gelei het. Eerder moet na die funksie van die gebed binne die verhaal gevra word as om dit by voorbaat as 'n bepaalde tipiese soort soos danklied of smeekgebed te tipeer en dit dan vanuit daardie perspektief te wil ver- 
klaar. Wie hierdie gebed ernstig opneem en dit interpreteer soos dit daar staan, begryp dat Jona se innerlike toestand tussen die twee pole van nood en verlossing wentel. Die gedig sluit egter af met 'n versekering dat die verlossing aan Jahwe behoort en moet dus as 'n danklied vir die verlossing beskou word. Nadat die vis hom uitgespoeg het, is hy weer ' $n$ keer die voorwerp van 'n handeling as Jahwe se opdrag in Jona 3:1 'n tweede keer na hom kom. Hierop reageer hy positief wanneer hy na Nineve toe reis om die boodskap wat aan hom opgedra is daar te preek. Uit hierdie gehoorsaamheid van hom kan in hierdie stadium niks van sy emosionele gesteldheid afgelei word nie, maar in Jona 4:2 word dit duidelik dat dit 'n gedwonge gehoorsaamheid was. Die heftigheid van sy reaksie in Jona 4:1 wys daarop dat, alhoewel hy aan Jahwe se eis voldoen het, dit teen sy eie beterwete was. Hierdie afleidings kan die leser egter eers ná Jona 4:2 maak, aangesien Jona in hoofstuk 3 oënskynlik sonder teenstribbeling aan Jahwe se eis toegee. Die kalme manier waarop Jona optree, is dus bedrieglik en weerspieël nie sy ware gemoedstoestand nie. Barkhuizen (1988:60) se waarneming dat daar geen terugverwysing na Jona se verlede voorkom nie, is dus nie heeltemal gegrond nie - hiervan getuig Jona 4:2.

Implisiete informasie oor die psigologiese toestand van Jona kan volgens bogemelde skema op twee verdere maniere uit die karakterteks afgelei word. Ter wille van praktiese oorwegings word hierdie twee maniere, wat as die karakter se gesprekke onder 2.2.2 en as die karakter se spraakhandeling onder 2.2.4 in die skema genoem is, hier in een paragraaf behandel. Dit word gedoen omdat dit logies is dat, terwyl die karakter se gesprekke vir inligting oor sy geestesgesteldheid gefynkam word, daar terselfdertyd ook gelet kan word op die manier hoe hy dinge sê. Wat opmerklik is van Jona se gesprekke, is die formele aard daarvan. Wanneer hy op die matrose se bombardament van vrae antwoord, doen hy dit nie in sy eie woorde nie, maar met formele uitdrukkings soos 'en ek vrees Jahwe, die God van die hemel wat die see en die droë grond gemaak het' (Jona 1:9). Hierdie plegstatige belydenis in antwoord op die matrose se direkte en informele vrae, skep onmiddellik afstand tussen Jona en die seelui. Verder word Jona se ware gevoelens ook deur hierdie formele taalgebruik verbloem. Ook op hulle verbasing en hulle vraag wat hulle met hom moet doen, antwoord hy direk en sonder emosie. Die volgende keer wanneer Jona aan die woord kom, is binne die maag van die vis. Alhoewel die gebed 'n ekU-verhouding veronderstel, is dit in der waarheid 'n monoloog (contra Barkhuizen 1988:64; vgl Gräbe 1984:24). Omdat hierdie monoloog poësie is en ook van geykte terminologie en 'n geykte vorm gebruik maak, vertoon dit 'n formele aard. In hoofstuk 3 is daarop gewys dat al hierdie geykte elemente op 'n unieke en geniale wyse gekombineer word om Jona se reaksie op die gebeure weer te gee. Die reaksie ontbloot enersyds sy emosionele toestand en andersyds word dit deur die formele ka- 
rakter van die geykte vorm verskuil. Ook in Jona 3:4, wanneer Jona teen Nineve preek, is sy woorde uiteraard formeel. Dit is egter te verstane omdat hy daarmee net as boodskapper optree om die woorde van Jahwe aan Nineve deur te gee. Wanneer Jona in Jona 4:2 bid, is dit nog eens formeel, want ook hierdie gebed is poësie soos dit in hoofstuk 3 betoog is. Hoewel formeel, verraai hierdie gebed egter intense emosie - van verwyt, van verontskuldiging en van oorgawe. Hierdie oorgawe in Jona 4:3 word 'n refrein wat in Jona 4:9 herhaal word, sodat enersyds die geyktheid behou word en andersyds die finale oorgawe daardeur vergestalt word. Opvallend van al Jona se gesprekke is dat hy nêrens die inisiatief tot gesprekvoering neem nie, maar dat hy slegs reageer op wat ander karakters doen, of spesifiek van hom vra. Verder is sy reaksie ook deurgaans formeel. Die vraag wat nou beantwoord moet word, is waarom dit die geval is. Heel waarskynlik is die antwoord daarin geleë dat hy as die antagonis die strewe van Jahwe nie kan aanvaar nie en daarom glad nie daarby betrokke wil raak nie. Deur formeel te bly en net te reageer wanneer dit van hom verwag word, kan hy sy onbetrokkenheid handhaaf. Dit weerhou die leser egter nie om belangrike afleidings ten opsigte van Jona se psigologiese toestand te maak nie. Plek-plek soos in die gebede, kom daar selfs, ten spyte van die formele aard daarvan, onbewustelik meer van sy geestestoestand na vore.

Omdat perspektief as 'n wyse waarop informasie deurgegee word in die volgende hoofstuk as deel van die vertelhandeling behandel word, sal daar nou direk oorgegaan word na die tegnieke van informasieoordrag:

* Ooreenkomstig die model wat hierbo gegee is, is die eerste tegniek waarmee informasieoordrag geskied, naamgewing. Dit is reeds bekend dat die naam van hierdie karakter Jona, seun van Amittai is. Omdat hierdie naam uit 2 Konings $14: 25$ bekend is as die naam van 'n profeet uit die agste eeu, is dit nie vergesog om hierdie twee karakters met mekaar te identifiseer nie. Daarmee word 'n historiese figuur binne 'n bepaalde konteks en met 'n bepaalde konnotasie as hoofkarakter van 'n latere verhaal gebruik. Met die naam 'Jona, seun van Amittai' word vir die ingeligte leser of hoorder 'n hele verwysingsraamwerk opgeroep, soos byvoorbeeld dat hy 'n nasionalistiese profeet was wie se heilsprofesie vir sy volk bewaarheid is. Onmiddellik wanneer hierdie naam dus aan die begin van hierdie verhaal genoem word, word inderdaad baie meer inligting verskaf as wat op die oog af voorkom. Met die verloop van die verhaal, soos wat meer en meer karaktertrekke bekend word, word die aanvanklike voorkennis uit 2 Konings 14:25 bevestig. Vroeër (4.3.2) is reeds op die sisteem van benoeming gewys waar slegs Jona en Jahwe met eiename benoem word en alle ander karakters slegs deur omskrywing. Elke keer wanneer hierdie eienaam in die teks voorkom, word die karakter nie alleen teenwoordig gestel nie, maar het dit 
ook verandering ondergaan. Dié Jona van wie daar in Jona 3:1 melding gemaak word, is nie meer dieselfde Jona wat aanvanklik in Jona 1:1 aan die leser bekend gestel is nie. Net so het die Jona van Jona 4:9'n radikale verandering ten opsigte van die Jona in 3:1 ondergaan. Selfs die Jona wat 'n geïmpliseerde antwoord op Jona 4:10-11 sou gee, verskil van die Jona in 4:9 omdat hy tot 'n bepaalde insig moes kom - dié insig wat in Jahwe se strewe vervat is. Vanaf Jona 1:1-4:11 vind daar ' $n$ toenemende proses van blootlegging of karakteropenbaring van die eintlike Jona plaas. Nadat Jona in Jona 1:1 met volle naam en afkoms en die sinspelings daaraan verbonde, aan die leser voorgestel is, word in die res van die boek slegs met sy voornaam of selfs met pronominale suffikse na hom verwys.

* Herhaling is as deel van frekwensie by die tydsaspek uitvoerig behandel. Daar het die klem primêr op die aantal kere geval wat 'n bepaalde gebeurtenis in die narratiewe teks vertel word. Hier verskuif die klem na die manier waarop herhaling gebruik word om informasie in verband met die karakter weer te gee. Deur herhaling word 'n karakter nie alleen in die teks teenwoordig gestel nie, maar word ook sy eienskappe na vore gebring. Daardeur word sy betekenis en funksie in die teks belig en ontwikkel. Dit is egter ook volgens Brink (1987:81) belangrik om daarop te let hoe die herhaling geskied. In die vertellersteks word in Jona 1:1-3 herhaal dat Jona van Jahwe se opdrag wegviug. Hierdie onwilligheid om te gehoorsaam word beklemtoon deur die noodsaak om die opdrag aan Jona te herhaal om na Nineve te gaan (Jona 3:1). Wanneer Jona in sy gebed (Jona 4:2) motiveer waarom hy hierdie opdrag verontagsaam, word 'n addisionele klem ook in die karakterteks op sy ongehoorsaamheid geplaas. In die vertellersteks word deur die herhaling van die wondergebeure gedemonstreer tot watter uiterstes Jahwe moes gaan om 'n gesindheidsverandering by Jona te bewerkstellig. Wanneer hy by die wondergebeure baat, ken sy dankbaarheid en vreugde geen perke nie, maar wanneer die wondergebeure ongunstig vir hom is, vra hy om te sterf. Omdat die versoek om te sterf elke keer herhaal word wanneer sake ongunstig vir Jona verloop, skep dit die indruk van ontevredenheid en dat hy soos 'n stout kind is wat, sodra hy nie sy sin kry nie, moed opgee. In die twee gebede van Jona, tesame met die versoek in Jona 4:8, word in die karakterteks klem gelê op die feit dat, alhoewel hy ongehoorsaam was, hy tog ten tye van groot emosionele spanning hom onmiddellik tot Jahwe wend. Deur herhaling word karaktertrekke van Jona soos eiesinnigheid en ongehoorsaamheid, maar ook sy afhanklikheid van Jahwe beklemtoon.

* Akkumulasie is 'n tegniek waardeur die soort en die verskeidenheid van eienskappe wat rondom 'n eienaam geweef word, geïdentifiseer word (Brink 1987: 
82). Dit is egter ook noodsaaklik om aan te toon hoe hierdie eienskappe mekaar aanvul, maar ook mekaar relativeer om 'n geheelbeeld van die karakter te vorm. Aan die negatiewe kant van Jona se persoonlikheid is daar, benewens sy reeds genoemde eiesinnigheid en ongehoorsaamheid, ook sy ongeërgdheid oor die lotgevalle van ander mense. Hierdie ongeërgdheid manifesteer later in 'n byna wraakgierige afwagting op die voltrekking van Jahwe se oordeel oor Nineve in Jona 4:5. Aan die positiewe kant is daar sy eties korrekte optrede wanneer hy teenoor die matrose bieg dat hy die oorsaak van die storm is en dat hy ook bereid is om daarvoor oorboord gegooi te word. Aan die een kant probeer hy Jahwe se opdrag ontduik, maar aan die ander kant kan hy nie anders as om tot Jahwe te bid wanneer hy ontsteld is nie. Hierdeur word 'n karakter geskets wat enersyds gedetermineerd is om sy eie wil te volg en andersyds nie van sy afhanklikheid van Jahwe kan ontvlug nie. Die negatiewe word dus deur die positiewe gerelativeer. Só word die volgende stelling van Coats (1985:84) bewaarheid, naamlik: 'Through a compact series of events or stress situations a character is made clear and distinct to the reader or a situation's true quality is revealed.' Die kompleksiteit van die Jonakarakter word deur middel van akkumulasie in die verloop van die verhaal onthul.

* Transformasie is die volgende tegniek waardeur informasie oorgedra word. Hoewel hierdie studie en dié van Nel (1988:1-12) grootliks dieselfde konklusies deel, word daar van $\mathrm{Nel}$ (1988:12) verskil wanneer hy beweer dat die Jonakarakter geloofwaardig is omdat hy enduit konstant bly. Egri (1960:212) stel tereg: 'Without transition there cannot be development or growth...And transition is the element which keeps the play [story] moving without any breaks, jumps or gaps. Transition connects seemingly unconnected elements....' (my toevoeging). In 'n goeie verhaal geskied hierdie oorgange nie met spronge nie, maar met verdrag en volgens bepaalde stadia tussen die pole (Egri 1960:194). Daarom is dit logies dat die Jona van Jona 1:1 sal verskil van die Jona wat in 4:10-11 geskets word - dit is reeds by die bespreking van die psigologiese dimensie bespreek. Die transformasie van die Jonakarakter vind plaas tussen die twee pole van onwilligheid en gewilligheid om die strewe van die protagonis te aanvaar. Dit kan op die volgende wyse geskematiseer word: 


\begin{tabular}{|c|c|c|c|}
\hline Protagonis & - Jahwe & Antagonis & - Jona \\
\hline $1: 1-3$ & - opdrag & $\begin{array}{l}\text { houding } \\
\text { handeling }\end{array}$ & $\begin{array}{l}\text { - onwilligheid } \\
\text { - ongehoorsaamheid }\end{array}$ \\
\hline $1: 4-16$ & - storm & $\begin{array}{l}\text { houding } \\
\text { handeling }\end{array}$ & $\begin{array}{l}\text { - onbetrokkenheid } \\
\text { - slaap }\end{array}$ \\
\hline $2: 1-11$ & - vis & $\begin{array}{l}\text { houding } \\
\text { handeling }\end{array}$ & $\begin{array}{l}\text { - dankbaarheid } \\
\text { - gebed }\end{array}$ \\
\hline $3: 1-3$ & - opdrag & $\begin{array}{l}\text { houding } \\
\text { handeling }\end{array}$ & $\begin{array}{l}\text { - gewilligheid? } \\
\text { - gehoorsaamheid? }\end{array}$ \\
\hline 3:10 & - begenadiging & $\begin{array}{l}\text { houding } \\
\text { handeling }\end{array}$ & $\begin{array}{l}\text { - woede } \\
\text { - gebed }\end{array}$ \\
\hline $4: 6$ & - boompie & houding & - groot vreugde \\
\hline $4: 7-9$ & - wurm en wind & $\begin{array}{l}\text { houding } \\
\text { handeling }\end{array}$ & $\begin{array}{l}\text { - doodswens } \\
\text { - versoek }\end{array}$ \\
\hline $4: 10-11$ & - vraag & houding & - geïmpliseerde gewilligheid \\
\hline
\end{tabular}

Uit hierdie spektrum van transformasies kan die geleidelike oorgang tussen die twee pole van onwilligheid tot gewilligheid om die protagonis se strewe te aanvaar, duidelik waargeneem word. Daarmee word voldoen aan die vereiste wat Egri (1960:212) stel dat transformasie die element is wat die verhaal laat aangaan 'without any breaks, jumps, or gaps. Transition connects seemingly unconnected elements, such as winter and summer, love and hate'. In Jona se geval word die pole van onwilligheid met gewilligheid deur transformasie aanmekaar verbind.

* Die laaste tegniek waardeur informasie oor 'n karakter ingesamel kan word, is deur die dubbele proses van vergelyking en kontras. Deur dié proses kan enersyds die onderlinge eienskappe van 'n bepaalde karakter belig word en andersyds tussen verskillende karakters 'n onderskeid getref word. In Jona bring albei moontlikhede interessante gegewens na vore waardeur die leser in staat gestel word om 'n bepaalde konstruksie van die karakter te maak.

** Deur Jona se onderskeie optredes in die twee helftes van die boek te vergelyk en te kontrasteer, kom die volgende insiggewende informasie na vore: Ongehoorsaamheid in die eerste deel van die boek (Jona 1:1-3) word gekontrasteer met gehoorsaamheid in die tweede deel van die boek (Jona 3:13). In die eerste deel van die boek (Jona 1:9) getuig hy teenoor die matrose nadat hy deur die lot daartoe geforseer word. In vergelyking hiermee preek hy in die tweede deel van die boek (Jona 3:4), nadat Jahwe hom daartoe geforseer het deur die opdrag aan hom te herhaal. In die eerste deel van die 
boek (Jona 2:3-10) bid hy 'n wonderskone gebed wanneer hy uit die dood gered word. Die tweede deel van die boek (Jona 4:2-3) word hiermee gekontrasteer wanneer hy Jahwe in sy gebed verwyt, omdat Jahwe ander mense, naamlik die Nineviete, van die dood gered het.

** Wanneer Jona se optrede met die ander karakters soos die matrose en die Nineviete vergelyk word, is die kontras baie opvallend. Terwyl die matrose bang is en bid, en die vrag oorboord gooi om die skip en hulleself te red, gaan Jona af in die ruim, gaan lê en raak aan die slaap. Wanneer die matrose vra wat hulle met hom moet doen, antwoord hy doodluiters dat hulle hom oorboord moet gooi. Desnieteenstaande probeer die matrose om terug te roei land toe om Jona en hulleself sodoende te red. Terwyl hulle alles in werking stel (in die kaptein se woorde - Jona 1:6) 'sodat ons nie omkom nie', is Jona volkome bereid om oorboord gegooi te word en te sterf. Die matrose doen alles in hulle vermoë om die lewe te behou, maar vir Jona daarenteen skeel die dood glad nie. Nadat Jona oorboord gegooi is en die see stil geword het, voer die matrose weer drie handelinge uit wat van hulle oorgawe getuig (Jona 1:16), naamlik hulle vrees Jahwe, hulle bring offers aan Hom en hulle doen geloftes. Wanneer Jona deur die vis gered word, stem sy handelinge ook met dié van die matrose ooreen. In Jona 2:810 erken hy sy afhanklikheid van Jahwe, bring by lofoffers en doen geloftes aan Jahwe. Dit is merkwaardig dat Jona die heidene se voorbeeld in sy dankbetuiging vir die verlossing met presies dieselfde handelinge volg.

Terwyl Jona twee keer deur Jahwe gestuur moet word, hoef die Nineviete Jona se preek slegs een maal te hoor om onmiddellik met oorgawe daarop te reageer. Net soos die matrose in Jona 1:4, voer die Nineviete in hulle reaksie op Jona se preek ook drie handelinge uit: Hulle glo in God, hulle roep 'n vasdag uit en van groot tot klein trek rouklere aan as teken van verootmoediging (Jona 3:5). Jona, die profeet van Jahwe, moet twee keer opdrag kry voordat hy gehoorsaam, maar die Nineviete reageer oombliklik na slegs een waarskuwing. Om die kroon op hierdie reaksie te span, verootmoedig die koning homself ook deur van sy troon af te klim, rouklere aan te trek en in die stof te gaan sit. Daarby vaardig hy 'n dekreet uit wat selfs die diere van die stad insluit by hulle verootmoediging voor God, en wat sy hoogtpunt bereik met die wens 'sodat ons nie sal omkom nie' (Jona 3:9). Hiermee vorm Jona se afwagting van Jahwe se oordeel oor Nineve in Jona 4:5'n skrille kontras, veral as sy gebed om te sterf teenoor die koning se wens dat Nineve sal lewe, gestel word. 
** Die laaste en belangrikste vergelyking en kontras waardeur informasie oor die karakters gerekonstrueer kan word, is dié tussen Jona en Jahwe. Wat hierdie spesifieke vergelyking so belangrik maak, is die feit dat die protagonis en die antagonis met mekaar gekontrastreer word. Die kern van hierdie kontras is geleë in die strewe van die protagonis wat deur die antagonis teengestaan word. Jona het sy eie siening oor hoe Jahwe moet optree, al weet hy dat Jahwe juis nie so optree nie (Jona 4:2). Hy is ongehoorsaam en hy vlug en hy word kwaad wanneer Jahwe se optrede nie in ooreenstemming met sy eie begeertes is nie. Teenoor Jona se onwilligheid om iets met Nineve te doen te hê, neem Jahwe notisie van hulle slegte dade en stuur sy profeet om hulle daaroor aan te spreek - meer nog, Hy spaar hulle wanneer hulle tot inkeer kom. Aan die einde van die boek stel Jahwe dit pertinent dat Hy hulle onkunde in ag geneem het en hulle die geleentheid tot inkeer wou bied. Jona daarenteen wil niks met Nineve te doen hê nie en wanneer hy wel teen sy sin vir hulle gaan preek, gun hy hulle nie begenadiging nie. Indien Jahwe op dieselfde wyse teenoor Jona moes optree as die optrede wat Jona teen Nineve verwag het, sou Jahwe Jona ná sy aanvanklike ongehoorsaamheid moes ombring. Dit doen Jahwe egter nie, maar met groot geduld handel Hy met Jona deur die wonders van die vis (Jona 2:1,11) en die boompie (Jona 4:6-7) totdat Jona by implikasie (Jona 4:10-11) tot inkeer kom. In al sy handelinge bewys Jahwe dat $\mathrm{Hy}$ voldoen aan die belydenis wat Jona in Jona 4:2 uitgepreek het, naamlik: ' $U$ is ' $n$ genadige en barmhartige God, lankmoedig en vol liefde; en Een wat berou kry oor die onheil.' Venter (1986:320-322) toon myns insiens oortuigend aan dat die wondergebeure in die Jonaverhaal 'n 'karakterbeeldingstegniek van die verteller is om sy twee opponerende karakters uit te beeld'. Deur die gebruik van die werkwoord מנה 'beskik' word Jahwe as die Almagtige voorgestel 'wat kan doen soos wat Hy goed dink' (Jona 1:14). Hy gebruik hierdie almag nie alleen om te red nie (Jona 1:16; 2:11; 3:10), maar ook as 'n didaktiese middel om sy hardkoppige profeet tot ander insigte te bring (Jona 4:6-8).

Benewens die tegnieke wat hierbo bespreek is, word informasie ook deur taalhandeling weergegee. Hierdie saak is reeds onder 'implisiete informasie' in die vorige paragrawe aangeraak, toe daar op die formele aard van Jona se taalhandeling gewys is. Barkhuizen (1988:64) identifiseer vier dialooggeleenthede waarby Jona betrokke is. Twee daarvan is die gebede in Jona 2:3-10 en 4:2-3 wat volgens die betoog in hoofstuk 3 as poësie gelees moet word. Indien dit korrek is, moet hierdie twee gebede as monoloë en nie as dialoë beskou word nie (Gräbe 1984:24). Barkhuizen (1988: 
66) se afleidings oor die wisselling tussen die tweede persoon-styl en die derde persoon-styl is nie van toepassing nie, omdat hierdie wisseling tussen die persone 'n erkende konvensie binne die Psalms (en dus gebede) in die Ou Testament is. Slegs die tweede gebed (Jona 4:2-3) is in 'n dialoogsituasie in die vertelteks (Jona 4:4) ingebed. Hierdie dialoogsituasie word egter nie ontgin nie, want wanneer Jahwe op Jona se monoloog met 'n vraag reageer, antwoord Jona Hom nie. Hierdie swye van Jona is Jona 4:5 is een van die redes waarom daar vermoed is dat met die volgorde van die teks gepeuter is. Dié saak is reeds onder 'volgorde' by 4.2.1 aangesny (waar die teendeel voorgestel word). Die vraag is nou waarom Jona nie op Jahwe se vraag reageer en die dialoogsituasie sodoende laat ontplooi nie. Alter (1981:79) wys daarop dat die tegniek van swye ' $n$ bepaalde konvensie binne die Bybelse verhaalkuns is wanneer hy stel: 'The more common biblical practice, as we shall have occasion to see elsewhere, is simply to cut off one speaker in a dialogue without comment, leaving us to ponder the reasons for the interrupted exchange. When someone's silence is actually isolated for narration, we may infer that the refusal or avoidance of speech is itself a significant link in the concatenation of the plot.' Die dialoog word dus doelbewus afgesny en nie ontplooi nie, sodat die leser moet wonder wat die rede vir Jona se swye is. Klaarblyklik is die rede daarin te vind dat Jona nie wil antwoord nie, omdat hy nie kán antwoord nie. Natuurlik het Jona geen rede om kwaad te wees nie, behalwe dat hy nie wil toegee aan die strewe van Jahwe nie. Dit hang saam daarmee dat hy as nasionalistiese profeet en antagonis die strewe van Jahwe onaanvaarbaar vind.

Ten slotte moet daar enkele opmerkings oor die styl van die Jonaverhaal gemaak word. Die formele aard van Jona se redevoeringe is reeds hierbo behandel; tog is dit noodsaaklik om van die voorliefde wat die verteller vir bepaalde stylelemente openbaar, melding te maak. Die eerste voorliefde van die verteller is die gebruik van die hiperbool wat te voorskyn kom in die gebruik van die adjektief 'groot'. Afgesien van die stad wat groot is (Jona 1:2), word in die eerste hoofstuk van 'n groot wind (Jona 1:4), 'n groot storm (Jona 1:4,12), 'n groot vrees by die matrose (Jona 1:10,16) melding gemaak. Hierdie gebruik van die adjektief 'groot' word voortgesit in hoofstuk 2:1 met die groot vis en in hoofstuk 3 met die groot stad (Jona 3:2, 3). Benewens die attributiewe gebruik van 'groot', word die adjektief ook substantiwies gebruik in Jona 3:5, wanneer dit die kategorieë mense aandui wat rourites uitvoer en ook Jona 3:7, waar dit die hoë amptenare van die koning aandui. In hoofstuk 4 kwalifiseer die adjektief Jona se woede (Jona 4:1) sowel as sy vreugde (Jona 4:6); laastens verwys dit weer na die stad (Jona 4:11). Die stam word egter ook as werkwoord in Jona 4:10 aangewend. Behalwe om 'n bepaalde stemming in 
die verhaal te skep, funksioneer die hiperboliese gebruik van 'groot' ook as ironiese teenpool van die diminutiewe vorm van קיקיקו

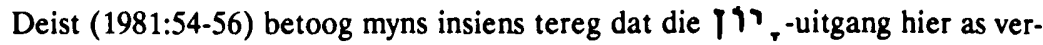
kleinwoord opgeneem moet word. In die lig van die belangrike rol wat kontras en ironie in die boek as geheel speel, is dit nie vergesog om hierdie voorbeeld as ' $n$ ironiese kontras te beskou nie. ' $n$ Tweede stylmiddel wat deur die verteller aangewend word, is die herhaaldelike gebruik van die figura etymologica, waar dieselfde stam as werkwoord en as objek van die werkwoord gebruik word. Hierdie stylmiddel word twee maal in hoofstuk 1 (Jona 1:10,16) aangewend wanneer die vrees van die matrose beskryf word. Daarna word dit ook twee maal in hoofstuk 4 ten opsigte van Jona gebruik wanneer eers sy woede in Jona 4:1 en daarna sy vreugde in 4:6 daarmee toegelig word. Dié styimiddel word by uitstek deur die verteller ingespan om oomblikke van intense emosie by bepaalde karakters uit te beeld. Die gebruik van hierdie stylmiddele naas andere, is die skrywer se manier waardeur hy nie alleen 'n godsdienstige karakter op 'n satiries-ironiese wyse wil tipeer nie, maar ook 'n bepaalde teologiese premisse wil tuisbring.

\section{B. Die karakterisering van Jahwe}

Daar is reeds betoog dat Jahwe die protagonis in die verhaal is; daarom vervul $\mathrm{Hy}$ die rol van katalisator binne die verhaal, sonder dat hy self karakterontwikkeling ondergaan. In Egri (1960:109) se woorde word dit so gestel: '[He] can match the emotional intensity of his adversaries, but he has a smaller compass of development.' Die feit dat Jahwe die protagonis is, beperk die beskrywing van sy karakter nog verder. Dit word bevestig deur Sternberg (1985:323) se opmerking: 'Though God is the Bible's hero, his portrayal may yet appear a special case. After all, most dimensions associoated with character - physical appearance, social status, personal history, local habitation - do not apply to him at all.' Die sleutel tot die karakterisering van Jahwe, ook in die Jonaverhaal, is geleë in sy handelinge. In die eerste drie hoofstukke word Jahwe deur die leser geken soos wat die verteller Hom deur middel van sy handelinge beskryf. Daar word wel indirek in Jona 1:1 en 3:1 van Jahwe se woord gepraat sonder dat die inhoud daarvan woordeliks weergegee word. Eers in Jona 4:4 kom Jahwe direk aan die woord wanneer hy Jona oor sy reaksie konfronteer. Omdat Jona swyg, kom die enigste dialoog waarby Jahwe betrokke is aan die einde van die verhaal in Jona 4:9-11 voor; daarom sal die meeste gegewens oor die karakter van Jahwe deur die leser uit sy optrede afgelei moet word. Daar is reeds na Venter (1986:320) se opmerking oor die wondervertelling as karakterbeeldingstegniek verwys: Hier is dit op Jahwe van toepassing. Vervolgens word dieselfde tegnieke wat gebruik is om informasie oor die Jonakarakter in te win - met die voorbe- 
houde wat hierbo gestel is - ook op Jahwe toegepas ten einde informasie oor sy karakter te verkry:

- Die naamgewing van die protagonis is baie meer gekompliseerd as wat dit die geval is met die antagonis. Afgesien van die voornaamwoorde waarmee na Hom verwys word, word ten minste vier stelle name vir die protagonis gebruik: In hoofstukke 1 tot 3, afhangende van wie na Hom verwys, word Hy Jahwe, Elohim, Ha-Elohim en Jahwe die God van die hemel genoem. Sy eienaam, Jahwe, word veral gebruik wanneer sy handelinge primêr tot sy profeet, Jona, gerig is. Die matrose en die mense van Nineve bid tot en glo in Elohim. Die kaptein en die koning spreek die wens uit dat Ha-Elohim hulle sal begenadig sodat hulle nie sal omkom nie. Jona bely dat hy Jahwe, die God van die hemel, dien en daarna, wanneer die storm rondom die matrose stil geword het, bid hulle ook tot Jahwe. Jahwe word dus in hierdie drie hoofstukke gereserveer vir die mense wat 'n spesifieke verhouding met die God van Israel het. Magonet (1976:33-38) wys daarop dat die Godsname in hoofstuk 4 volgens 'n bepaalde patroon gebruik word. Jahwe word in hierdie hoofstuk vir die genadige God gereserveer, terwyl Elohim/Ha-Elohim gebruik word wanneer God sy skepsel onderrig om sy barmhartigheid te verstaan. Laasgenoemde benaming word dus in 'n dissiplinêre hoedanigheid gebruik. Van alle hipoteses oor die wisselende gebruik van die Godsname in die Jonaverhaal, soos dat dit op verskeie bronne van die verhaal sou dui, lewer die hipotese van Magonet die minste probleme, terwyl dit ook narratologies die meeste sin maak.

* Deur die tegniek van herhaling word heelwat informasie oor die protagonis deurgegee. In die vertellersteks herhaal Jahwe sekere handelinge tot die voordeel van die ander karakters. Eerstens herhaal Hy sy opdrag aan Jona, daarna red Hy eers die matrose, toe vir Jona en laastens spaar hy Nineve. Hy gebruik selfs wondergebeure om eerstens sy profeet te red en daarna, as 'n didaktiese middel, om hom tot ander insigte te bring. Beide die kaptein en die koning spreek die versugting uit dat God aan hulle sal dink sodat hulle nie sal omkom nie. Ook die matrose eggo hierdie versugting in hulle gebed, met die motivering dat Jahwe as vrymagtige God kan doen soos Hy wil. Aan al hierdie versugtinge voldoen God, maar meer nog, in Jona 4:10-11 verdedig Hy sy barmhartigheid teenoor Nineve in 'n gesprek met Jona. Jona self sluit sy gebed in Jona 2:3-10 af met die uitroep dat die redding aan Jahwe behoort, nadat hy 'n paar keer in sy gebed bely het dat Jahwe hom uit die nood gered het. Hierdie God kan egter ook bestraffend optree soos blyk uit sy motivering in Jona 1:2 dat $\mathrm{Hy}$ Jona na Nineve stuur omdat hulle sonde onder sy aandag gekom het. Wanneer sy profeet wegvlug, bring God 'n storm op die see wat die skip, die matrose se 
lewens en ook Jona se lewe in die gevaar stel. Hierdie optrede van Jahwe bereik 'n klimaks wanneer $\mathrm{Hy}$ die boompie vernietig en die gloeiende Oostewind laat waai om sy profeet 'n les te leer.

* Uit die voorafgaande tegnieke is dit duidelik dat daar rondom die protagonis 'n aantal eienskappe akkumuleer waardeur die leser sy karakter beter kan leer ken. Al hierdie eienskappe dra daartoe by om die vrymag van Jahwe, soos dit deur die matrose in hulle gebed bely is, te illustreer. Sy geduld met sy profeet, sy medelye met mense in nood en sy reddende genade word nie net deur sy handelinge in die verhaal geillustreer nie, maar word ook pertinent deur Jona in Jona 4:2 met die volgende woorde saamgevat: ' Ja, ek het geweet dat $U$ 'n genadige en barmhartige God is - lankmoedig en liefdevol - en Een wat berou kry oor die onheil.' Wanneer die vrymag van God, soos dit uit al hierdie geakkumuleerde eienskappe blyk, boonop met humor, soos in die episode met die boompie gepaard gaan, kan die leser nie anders reageer as om saam met die matrose te bid nie: 'Want U is Jahwe - U doen soos wat U goed dink.' Sternberg (1985: 322) vat hierdie proses van akkumulasie baie goed saam in die volgende woorde: 'The complex of features making up God's portrait emerges only by degrees and only through the action itself,...the reader must piece it together for himself by extrapolating features from dramatic givens.'

* Omdat die protagonis die katalisator van die verhaal is, wat dinge laat gebeur, kan daar nie werklike sprake van transformasie in sy karakter wees nie. Om sy premisse te verwesenlik sal Hy niks ontsien om sy doel te bereik nie; daarom kan al sy handelinge gelees word in die lig van sy premisse om as die vrymagtige God erken te word. Jahwe tree konstant in ooreenstemming met hierdie premisse op en daarom is daar geen transformasie in sy karakter teenwoordig nie.

* Die informasie oor Jahwe wat deur die tegniek van kontras en vergelyking gekonstrueer kan word, is reeds onder dieselfde hoof wat betrekking het op die Jonakarakter behandel.

\subsection{Ruimte}

Volgens Bal (1980:16) se beskouing vorm 'gebeurtenissen, acteurs, tijd en plaats samen het materiaal van de geschiedenis'. Vir hierdie onderdele van die storie of geskiedenis gebruik Bal die term 'elementen'. Alhoewel ruimte algemeen as een van die vier elemente van die verhaal naas gebeurtenisse, karakters en tyd aanvaar word, word dit byna altyd of afgeskeep of totaal genegeer. So maak Genette se model (wat as uitgangspunt vir die bespreking van die narratiewe kategorieë in hierdie hoofstuk gebruik is) glad nie voorsiening vir ruimte as 'n aparte entiteit nie. Tog is 
ruimte so 'n belangrike komponent van enige verhaal en in die besonder ook van Jona, dat dit nie agterweë gelaat durf word nie. Trouens, sonder die bespreking van ruimte as element van die verhaal, sou die bespreking nie alleen onvolledig wees nie, maar ook uiters onbevredigend omdat 'alles wat in die vertelteks gebruik word om [gewoonlik in samehang met tyd] 'n situasie te konstitueer waarbinne "iets met iemand gebeur", tot die konsep van narratiewe ruimte behoort' (Brink 1987:108). Daarom is dit noodsaaklik dat Genette se model op hierdie punt gewysig of aangevul moet word.

In hierdie paragraaf word uitgegaan van die model wat deur Van Eck uitgewerk is. Die model het aanvanklik sy ontstaan in 'n artikel oor die funksie van ruimte in die narratologie gehad (Van Eck 1986:339-349), maar dit is later verder uitgewerk in 'n hoofstuk van sy ongepubliseerde verhandeling (Van Eck 1989). Hierin wys hy daarop dat ruimte onontbeerlik is vir die verstaan van die verhaal, maar dat dit op 'n ander wyse as die ander drie elemente in die narratologie gehanteer moet word. In sy model maak hy wel gebruik van wat ander literatuur-teoretici oor ruimte gesê het, maar hy verwerk dit op 'n unieke wyse. In hierdie model gaan hy uit van die volgende twee veronderstellings:

* Ruimte, net soos die ander elemente van die verhaal, moet sy regmatige plek in die bespreking van die verhaal kry.

- Ruimte, anders as die ander elemente, kan net op die vlak van die récit bespreek word en nie as 'n relasie tussen die verskillende verhaalvlakke nie. Volgens hierdie model kan daar dus nie by ruimte 'verdubbeling' soos by tyd plaasvind nie.

Vervolgens word die drie aspekte van ruimte bespreek waardeur die funksionering van ruimte binne die verhaal nader toegelig word.

In die eerste plek dui die term 'ruimte' op alles wat in 'n vertelling ruimtelikheid besit:

* Dit kan die plek wees waarbinne die karakters hulle bevind. In Jona se geval sal dit plekke soos Israel, die skip, die vis en Nineve wees.

* Dit kan ook toebehore van ruimte wees soos die skip se ruim en die boompie buite die stad.

* Dit kan ook die wyse wees waarop ruimte voorgestel word soos die stormagtige see en die warm wind en die gloeiende son buite die stad.

* Dit kan ook die gevoelswaarde wees wat aan bepaalde ruimtes geheg word. 'n Bepaalde ruimte kan dus of positief of negatief ervaar word. So word die skip se ruim aanvanklik deur Jona as 'n geborge ruimte en dus positief ervaar, maar 
as gevolg van die storm wat deur Jahwe bewerkstelling word, verander dit in 'n negatiewe ervaring.

- Dit kan ook soms nie-ruimtelike begrippe ruimtelik voorstel soos wanneer Jona van Jahwe praat as die God van die hemel, wat die see en die droë grond geskape het.

In die tweede plek is ruimte binne die vertelling 'fiktiewe ruimte', dit wil sê, dit is 'n literêre katagorie binne die vertelde wêreld. Dit is dus die wêreld waarin die kommunikasieproses afspeel (Van Eck 1986:343). Hoewel hierdie fiktiewe ruimte ooreenkomste kan vertoon met die reële wêreld, gee dit nie die ruimte van die reële wêreld presies net so weer nie. Die geloofbaarheid van 'n verhaal en daarom ook van die Jona-verhaal is dus nie afhanklik van die feitelike korrektheid van ruimtelike gegewens soos byvoorbeeld Nineve se grootte nie. Dit is egter noodsaaklik dat daar wel raakpunte tussen die fiktiewe en reële wêrelde sal wees sodat die vertelde wêreld vir die leser aanvaarbaar sal wees. In terme van die Jonaverhaal moes Nineve, met alles wat dit simboliseer, ooreenstem met die verwysingsraamwerk wat die eerste lesers daarvan gehad het. Hierdie aanvaarbaarheid van die fiktiewe wêreld vir die leser moet egter ook verband hou met die konvensie van 'n bepaalde genre. Binne die konvensie van die sprokiegenre is dit aanvaarbaar dat diere kan praat. Net so was dit vir die implisiete lesers van die Jonaverhaal geen probleem om te aanvaar dat Jahwe 'n groot vis kan beskik om Jona in te sluk nie. Alhoewel hierdie bepaalde fiktiewe ruimte in terme van ons moderne wetenskapsbeskouing onaanvaarbaar is omdat dit nie met die reële werklikheid klop nie, het dit nie aanstoot gegee vir die siening van die eerste lesers nie. Die narratologie, deur die bespreking van die ruimte-element, kan juis 'n belangrike bydrae lewer om die feit te onderstreep dat ruimte (soos die vis se maag) enersyds 'n fiktiewe ruimte binne die vertelde wêreld is en andersyds dat hierdie ruimte binne 'n bepaalde narratiewe konvensie aanvaarbaar vir die lesers was.

In die derde plek funksioneer ruimte volgens Vandermoere (1976:33vv) op een van twee wyses, naamlik as speelruimte of belangeruimte. Waar speelruimte slegs lokaliteit aandui, kom belangeruimte tot stand wanneer daar ' $n$ verband tussen die karakterisering en ruimte gelê word. Volgens Blok se siening word laasgenoemde proses singewing genoem en dit geskied wanneer een of meer karakters 'n bepaalde ruimte persoonlik beleef ( $\mathrm{vgl}$ Van Eck 1986:344). Hierdie proses kan soos volg in Van Eck (1986:344) se woorde saamgevat word: '[D]it is duidelik dat ruimte tweeledig in 'n vertelling funksioneer. Deur dialoog word fiktiewe ruimte tot speelruimte gekonkretiseer en dit word belangeruimte wanneer dié beweging van 'n karakter of karakters liggaamlik of intensioneel persoonlik daaraan verbind word.' Hierdie be- 
langeruimtes word nie neutraal aangebied nie, maar word deur die karakters positief of negatief ervaar.

Wanneer bogenoemde aspekte op die Jona-verhaal toegepas word, blyk dit dat alle ruimtes belangeruimtes is en nie net blote speelruimtes is nie. Dit sal blyk wanneer die ses tonele waarby ruimte betrokke is vervolgens individueel bespreek word.

* Die eerste toneel waar Jahwe se roeping tot Jona kom, speel in Israel af. Omdat daar sprake is van dialoog, al is dit net indirek, word hierdie speelruimte 'n belangeruimte. Jona ervaar hierdie ruimte op 'n negatiewe wyse - daarom wil hy wegvlug na Tarsis. Omdat Jona nie na Nineve, wat hy as 'n negatiewe ruimte beskou, wil gaan nie, probeer hy ontvlug na Tarsis, wat hy as positief beskou. In Israel kan hy nie bly nie, want daardie belangeruimte is die ruimte waarbinne Jahwe se woord en opdrag uitgevoer moet word. Alhoewel hierdie belangeruimte vir Jahwe positief is, beleef Jona dit as negatief.

* Die tweede toneel speel af op die skip. Deur dialoog word ook hierdie speelruimte in 'n belangeruimte omskep. Aanvanklik beleef Jona hierdie ruimte op 'n positiewe wyse, want hy gaan af in die ruim, gaan lê en raak vas aan die slaap. Uit die aard van die saak is hierdie ruimte ook vir die matrose 'n positiewe ruimte, want dit is hulle arbeidsruimte. Deur Jahwe se ingrype met die storm, verander hierdie situasie totaal. Waar Jona hierdie ruimte eers as 'n veilige ruimte ervaar het, word dit nou omgekeer in onveiligheid. Ook vir die matrose is dit nou tot so 'n mate 'n negatiewe belewenis dat, ten spyte van al hulle pogings om die skip te red, die skip (volgens die verteller) op die punt staan om te vergaan. Eers wanneer Jona, nadat hy deur die lot as die skuldige uitgewys is, oorboord gegooi is, word die see rustig en die skip weer 'n positiewe belangeruimte vir die matrose. Omdat die skip as middel dien om Jahwe se strewe te dwarsboom, is dit vir Jahwe 'n negatiewe belangeruimte en daarom gebruik Hy die storm om dit na positief te verander.

* Die laaste toneel in die eerste helfte van die verhaal vind plaas binne die vis wat deur Jahwe beskik word om Jona in te sluk. Aangesien Jona in die maag van die vis tot Jahwe bid, verander ook hierdie ruimte van 'n blote speelruimte tot 'n belangeruimte. Anders as wat verwag kan word, is hierdie ruimte positief vir Jona. Hy het die dood verwag, maar word deur die vis van die dood gered. Die vis is vir beide Jona en Jahwe 'n positiewe belangeruimte: Vir Jahwe is die vis 'n middel om sy doel met Jona te bereik en vir Jona is dit die wyse waarop hy uit 'n watergraf gered word. Mitologies is die vis as monster uit die oseaan op 'n negatiewe wyse geïnterpreteer. Daar is geen rede waarom Jona dit nie ook op hierdie wyse sou ervaar nie. In die laaste twee tonele bewerkstellig Jahwe elke 
keer 'n omkering in die belangeruimtes waarbinne Jona verkeer. Die skip wat Jona aanvanklik positief beleef, word deur Jahwe in 'n negatiewe ruimte omskep; daarenteen word die vis wat deur Jona as negatief beleef word, deur Jahwe as middel ingespan om Jona op 'n positiewe manier te beïnvloed.

* Alhoewel dit nêrens eksplisiet gemeld word nie, speel die vierde toneel waarskynlik weer in Israel af. Dit kan afgelei word uit die feit dat Jahwe se woord 'n tweede maal tot Jona kom en dat daar dus weer 'n nuwe begin gemaak word. Dit is logies om te verwag dat hierdie nuwe begin in Jahwe se belangeruimte' $n$ aanvang sal neem. Die feit dat Jona Jahwe se opdrag gehoorsaam en nie meer daarvan probeer wegvlug nie, skep die indruk dat ook hy nou hierdie belangeruimte nie meer as negatief ervaar nie.

- Die vyfde toneel vind in Nineve plaas. Van die begin af het Jona negatief teenoor hierdie ruimte gestaan en dit word nou bevestig deur sy oordeelspreuk: 'Nog veertig dae en Nineve word verwoes.' Vir die inwoners van Nineve vir wie die stad uiteraard 'n positiewe belangeruimte is, is dit 'n traumatiese aankondiging waarop hulle met vrees reageer. Net soos dit die geval met die matrose was, reageer Jahwe gunstig teenoor hulle optrede en verander Hy die ruimte weer tot 'n positiewe belangeruimte vir die inwoners. Jona reageer hierop met woede en teleurstelling, want vir hom bly Nineve, vanweë sy ideologiese perspektief, 'n negatiewe belangeruimte.

* Dit is dan ook geen verrassing wanneer Jona Nineve verlaat om aan die Oostekant van die stad te gaan wag en waar te neem wat met die stad gaan gebeur nie. Hy beoog om vir homself ' $n$ skuiling te bou en sodoende vir homself ' $n$ positiewe belangeruimte daar te stel. Jahwe spring hom egter voor en Hy verskaf self die skaduwee wat Jona verlang. Dit verheug Jona, want oënskynlik keur Jahwe vir die eerste maal 'n belangeruimte goed wat hy as positief ervaar. Jona se vreugde was egter kortstondig en misplaas, want na slegs een dag vernietig Jahwe die boompie en word ook hierdie belangeruimte vir Jona negatief.

Uit die bogenoemde tonele is ' $n$ bepaalde skema oor die wisseling van belangeruimtes af te lei. Dit is merkwaardig dat alle ruimtes wat Jona self kies en daarom op 'n positiewe wyse ervaar, deur Jahwe in 'n negatiewe ervaring omskep word. Verder verander Jahwe twee maal vir die heidene hulle belangeruimtes terug van negatief na positief. Jahwe bewys ook dat Jona se belydenis oor Hom waar is, wanneer Jona Hom 'die God van die hemel wat die see en die vasteland gemaak het' noem. Dit doen Hy deur werklik alle belangeruimtes te beheers en volgens sy wil te verander. Hierdie opmerkings kan op die volgende wyse skematies weergegee word: 


\section{A}

B

1) Israel:

Positief vir Jahwe

Negatief vir Jona

2) Skip:

Negatief vir Jahwe

Positief vir Matrose

Positief vir Jona

Storm

Negatief vir Matrose

Negatief vir Jona

Reaksie van Matrose

Positief vir Jahwe

Positief vir Matrose

Negatief vir Jona

3) Vis:

Positief vir Jahwe

Negatief vir Jona

Gebed

Positief vir Jona

Positief vir Jahwe

4) Israel:

Positief vir Jahwe

Negatief vir Jona

5) Nineve:

Positief vir Jahwe

Positief vir Nineviete

Negatief vir Jona

Oordeelspreek

Negatief vir Nineviete

Positief vir Jona

Reaksie van Nineviete

Positief vir Jahwe

Positief vir Nineviete

Negatief vir Jona

6) Buite die stad:

Negatief vir Jahwe

Positief vir Jona

Boompie

Positief vir Jona

Negatief vir Jahwe

Wurm en Oostewind

Negatief vir Jona

Positief vir Jahwe

Bogenoemde skema, sover dit die belangeruimtes van die Jonakarakter betref, kan as volg vereenvoudig word:
1 Israel
4 Israel
2 Skip
5 Nineve
3 Vis
6 Buite die stad

Hieruit blyk dat tonele 1 en 4 teenoor mekaar staan, omdat Israel die plek is waar Jona beide kere sy opdrag ontvang. Vanweë die onaanvaarbaarheid van die eerste 
roeping, is die 'Israel' van toneel 1 'n negatiewe ruimte, terwyl die 'Israel' van toneel 4 noodwendig meer positief ervaar word wanneer Jona 'n tweede maal na Nineve gestuur word en die opdrag uitvoer. Tonele 2 en 6 korrespondeer met mekaar omdat dit die ruimtes is wat deur Jona self as positiewe ruimtes uitgesoek is, maar deur Jahwe in negatiewe ruimtes vir Jona verander is. Daarenteen is tonele 3 en 5 ruimtes wat deur Jahwe vir Jona bestem is en alhoewel dit aanvanklik vir Jona 'n negatiewe konnotasie ingehou het, is dit later deur hom op 'n positiewe manier beleef.

Uit die bespreking van ruimte blyk dit dat ruimte nie alleen 'n onontbeerlike element van die verhaal is nie, maar dat dit ook sekere gegewens bevestig wat by die ander elemente na vore kom. So korreleer die waarneming wat by die bespreking van tyd ten opsigte van Jona 4:5 gemaak is nou ook met dit wat by die bespreking van ruimte daaroor bevind is. Omdat dit 'n nuwe speelruimte en ook 'n nuwe belangeruimte aandui, kan dit nie ná Jona 3:4 ingeskuif word nie. Ook wat karakterisering betref, lewer ruimte ' $n$ baie belangrike bydrae tot die verstaanbaarheid van karakters se handelinge. 